\title{
The Rise and Fall of Fannie Mae and Freddie Mac: Lessons Learned and Options for Reform
}

\author{
By \\ Richard K. Green and Ann B. Schnare \\ November 19, 2009 \\ Empiris LLC \\ 2100 M Street NW, Suite 604 \\ Washington DC 20037
}

This paper was prepared by Empiris, LLC under contract to Genworth Financial Corporation. All opinions expressed are those of the authors. Richard Green is Professor, School of Policy, Planning and Development and Marshall School of Business, and Director, USC Lusk Center for Real Estate. While he has spent most of his career as an academic, Dr. Green did a brief stint at Freddie Mac from 2002 to 2003. Ann Schnare is a Partner at Empiris, LLC. From 1993 through 2000, Dr. Schnare was Senior Vice President for Corporate Relations and Vice President for Housing Economics and Financial Research at Freddie Mac. 


\section{Executive Summary}

Not so long ago, the US housing finance system was arguably the best in the world. Consumers had access to products that were not available elsewhere, and the market was able to sustain major economic disruptions with relatively little impact on either the cost or availability of mortgage credit. Fannie Mae and Freddie Mac (hereafter the GSEs ${ }^{1}$ ) provided the cornerstone of that system and deserve much of the credit for its success.

But despite their many accomplishments, Fannie Mae and Freddie Mac are now essentially wards of the state and most policymakers have concluded that the GSE model is effectively dead. This paper attempts to establish a case for GSE reform that retains a market-driven approach but addresses acknowledged problems through charter revisions and better regulation.

\section{How Fannie Mae and Freddie Mac Support the Mortgage Market}

Fannie Mae and Freddie Mac have two basic lines of business: the "guarantee" business and the "mortgage investment" business. Both activities help to support the secondary market for residential loans.

The guarantee side of the GSEs' business involves the securitization of mortgages, i.e., purchasing loans from lenders, bundling the loans into mortgage-backed securities (MBS), and selling the securities through Wall Street firms. Fannie Mae and Freddie Mac assume the underlying credit risk on the mortgages they securitize in exchange for a guarantee fee. Because of their government ties, investors have traditionally seen this guarantee as carrying the full faith and credit of the federal government. The outstanding securities of the GSEs now stand at approximately $\$ 5$ trillion.

The investment side of the GSEs' business involves their retained mortgage portfolios, which include whole loans, their own MBS, and "private label" securities primarily backed by multifamily, subprime and Alt-A mortgages. The GSEs fund their investment portfolios by issuing corporate debt, and generate income from the spread between the interest rates on their mortgage holdings and their funding and hedging costs. The GSEs' combined portfolio holdings are now roughly $\$ 1.6$ trillion.

Until recently, the risks associated with these two lines of business were distinctly different. Securitization primarily exposed the GSEs to credit risk, i.e., the risk that the loans default. Since their securities are sold into the capital market, investors-as opposed to the GSEs-assume the "interest rate" risk. Traditionally, the investment side of the GSEs' businesses mainly exposed them to interest rate risk. Since Fannie Mae and Freddie Mac primarily invested in their own securities, no additional credit risk was involved. However, this situation changed

\footnotetext{
${ }^{1}$ For ease of exposition, we use the term GSE to refer only to Fannie Mae and Freddie Mac. Our comments do not include references to the Federal Home Loan Banks, which are another form of GSE.
} 
in recent years as both GSEs began to invest heavily in "private label” securities, which are typically not insured.

\section{GSE Mission and Accomplishments}

In order to understand how one could improve upon the existing GSE model, one first needs to understand their original mission and purpose. While their early histories differ, both Fannie Mae and Freddie Mac have identical charter objectives, namely, to:

- Create a liquid and reliable secondary market for residential mortgages;

- Respond appropriately to the needs of the capital market; and

- Improve the distribution of mortgage credit by promoting broader access to affordable mortgage finance.

In our view, Fannie Mae and Freddie Mac have been quite successful in achieving these basic objectives.

\section{Standardization}

One of the GSEs' first and most important accomplishments was to standardize the origination, underwriting and securitization processes. Standardization served to commoditize residential mortgages, which led to efficiencies and lower costs, and generally created the conditions required for a highly liquid secondary market. For many years, Fannie Mae and Freddie Mac also set the standard for determining an "acceptable" level of credit risk. While both GSEs loosened their underwriting standards at the height of subprime lending boom, for most of their histories Fannie Mae and Freddie Mac concentrated on relatively conservative products whose performance was well-understood and easily evaluated by investors.

\section{Liquidity}

The GSEs also helped to create a highly liquid mortgage market. Mortgages, by their very nature, are illiquid financial instruments that appeal to relatively few investors. By pooling loans into mortgaged-backed securities, Fannie Mae and Freddie Mac broadened the investor base by enabling investors to purchase shares of the underlying mortgages as opposed to the mortgages themselves. Because of their special status, most investors believed that the GSEs' securities carried the implicit backing of the federal government, thereby eliminating the need to conduct an independent assessment of the quality of the underlying loans.

\section{Stability}

In addition to liquidity, the GSEs also created a stable and reliable flow of mortgage funding, an outcome that was the likely result of their implicit guarantees. The importance of a government guarantee to the stability of the mortgage market has never been more evident than it is today. 
The private securitization market has collapsed, and nine out of every ten mortgages are now being funded through the GSEs or insured through FHA. However, although the current situation is extreme-and ultimately required the direct intervention of the Federal Reserve to maintain the market for the GSEs' securities-the stabilizing influence of the GSEs has been seen before. For example, while the 1998 default on Russian bonds and the collapse of Long Term Capital caused financial markets to freeze around the world, conventional conforming mortgages continued to be widely available at historically low interest rates. The same was true after 911.

\section{Improved Access to Affordable Mortgage Finance}

The GSEs have also played an important role in improving access to affordable mortgage finance. Regional disparities in the availability of mortgage funding have largely been eliminated, mortgage rates are lower by 25 to 50 basis points on average, and families have access to low downpayment, 30-year fixed rate conventional loans. The GSEs also continue to play an important role in providing a securitization outlet for smaller, less highly capitalized institutions such as community banks, thereby helping to channel capital into communities that might not be otherwise served.

However, the GSEs have generally been less successful in serving more targeted segments of the population, as defined by their Affordable Housing Goals. While the GSEs have typically met their housing goals, most studies have found little, if any evidence that their activities have been particularly effective compared to those of portfolio lenders. This outcome may reflect the wholesale nature of the GSEs' operations as well as the fact that Fannie Mae and Freddie Mac were neither required nor inclined to subsidize lending to targeted groups. Indeed, some have argued that the Affordable Housing Goals ultimately brought the GSEs down by encouraging them to lower their underwriting standards and invest heavily in subprime securities.

\section{Weaknesses of the GSE Model}

While Fannie Mae and Freddie Mac were highly successful in achieving their charter objectives, there are a number of inherent weaknesses in the GSE approach.

\section{Moral Hazard}

Perhaps the most persistent criticism is the moral hazard that arises from the government's implicit guarantee. Since the guarantee is provided free of charge-and presumed to apply to GSEs' securities and corporate debt--critics have long maintained that Fannie Mae and Freddie Mac took on excessive risk in order to maximize shareholder profits and executive compensation, with federal taxpayers left holding the bag. This "privatization of profits and socialization of risk" has become a rallying cry for many GSE detractors. In fact, many believe that the moral hazard inherent in the GSE approach was the primary driver behind their demise. 


\section{Too Big to Fail}

Another related concern was that the GSEs had simply become too big to fail. GSE securities are subject to favorable capital treatment and constitute a significant part of banks' portfolio holdings. As a result, a significant deterioration in their market value would trigger a wave a secondary effects that could ultimately threaten the banking system. GSE debt and securities have also become integral parts of global capital markets, with much of it held by foreign countries. As a result, the potential collapse of either GSE could have international repercussions that transcend the US housing market. While the charge of "too big to fail" is hardly unique to the GSEs, systemic risk is a legitimate concern. The challenge is how to achieve the volume required for market liquidity with less concentration and lower risk.

\section{Lack of Competition}

Critics have also charged that the lack of competition between the two GSEs has led to excess profits and reduced the benefits that would have otherwise been received by consumers. While economic theory suggests that duopolies can be highly competitive, whether this applies to Freddie Mac and Fannie Mae is a matter of some debate. Unless returns are regulated, two GSEs are clearly better than one. However, the "appropriate" number of GSEs going forward is an open issue. While additional GSEs would undoubtedly enhance competition, multiple security issuers would tend to undermine the liquidity of the MBS.

\section{Concentration of Risk}

Another criticism of the GSE model is that it led to an unnecessary concentration of risk. Ironically, this argument typically focused on the GSES' growing portfolios and their increased exposure to interest rate risk. While it was widely recognized that the GSEs played an important role in the geographic diversification of credit risk, relatively little attention was paid to the fact that as their market share increased, credit risk became increasingly concentrated in their hands. In the end, it was credit risk, not interest rate risk that brought the GSEs down. However, the GSEs' losses to date are largely attributable to their purchases of Alt-A mortgages and subprime securities as opposed to "traditional" conforming loans.

\section{Inadequate Capital Standards}

With the advantages of hindsight, it is also clear that the GSEs' capital standards were insufficient to protect them from the meltdown of the housing market that began in late 2006. The GSEs were required to meet a capital ratio of 2.5 percent, or a "risk-based capital" requirement, whichever was higher. While risk-based capital standards were not implemented until 2002, the minimum capital requirement remained the binding constraint in subsequent years. In 2007, Freddie Mac's risk-based capital requirement was only 53 percent of its minimum capital standard. Yet within a year, Freddie Mac had a regulatory capital deficit of $\$ 41.3$ billion. Thus, despite the best intentions - and sophisticated analyses that were used to 
develop the standards and determine capital adequacy-the GSEs' capital requirements ultimately proved to be inadequate.

\section{Political Influence and Weak Regulatory Oversight}

Finally, no discussion of the GSEs would be complete without reference to their enormous political influence on Capitol Hill. Until their government takeovers, Fannie Mae and Freddie Mac were among the nation's largest political contributors, and their largess was directed to Democrats and Republicans alike. Such activities served to protect the GSEs from repeated efforts to reign in their activities by their federal regulator, unsympathetic members of Congress, and both the Clinton and Bush Administrations. While aggressive lobbying activities are hardly unique to the GSEs, their political maneuverings ultimately precluded meaningful oversight by their federal regulator, the Office of Federal Housing Enterprise Oversight (OFHEO), whose regulatory powers were considerably weaker than those of other enforcement agencies.

\section{Principles for Reform}

The recent history of the GSEs and the broader mortgage market suggest several guiding principles that should govern any reform.

\section{Strong Regulation and Appropriate Capital Standards}

The experience of the past two years clearly demonstrates the importance of strong regulatory oversight and meaningful capital standards. While the Housing and Economic Recovery Act of 2008 created a new GSE regulator-the Federal Housing Finance Agency (FHFA)—with significantly broader authorities and enforcement powers, it did so after most of the major damage had been done. Going forward, FHFA (or its successor) must continue to have the power and independence it needs to provide meaningful oversight, including the authority to adjust capital requirements on an as-needed basis.

\section{Explicit Guarantee}

The experience of the past two years has also demonstrated the importance of a government guarantee in ensuring an adequate flow of mortgage funding in good times and bad. It is time to make the guarantee explicit. Even if one wanted to return to an "implicit" guarantee, the market would not believe it. It is better to provide an explicit guarantee--and be able to charge for itthan to continue with an approach that is the functional equivalent of “Don't ask, don't tell." At the same time, the guarantee should be structured in such a way that reduces moral hazard as much as possible. While recent events admittedly make this difficult to achieve-any large financial institution may now be viewed as too big to fail—some options are clearly better than others in this regard. 


\section{Market-driven Approach}

In our view, any reform should also preserve the market-driven approach that was one of the major strengths of the GSEs and the source of much of their innovation. It is difficult to imagine how a government-owned entity-whether independent or part of another agency—could have produced the many socially valuable innovations that were spearheaded by the GSEs. At the same time, a market-driven approach requires meaningful competition. As a result, providing monopoly power to one or two institutions is probably not the way to go.

\section{Appropriate Risk Sharing}

Proposals to reform the current system should also encourage risk sharing in order to align incentives and provide another "set of eyes" in the underwriting process. The current GSE model already has important risk-sharing elements embedded in its design, including requirements that low downpayment loans have mortgage insurance or other forms of credit enhancement. Additional risk-sharing arrangements should be considered. However, any requirements should be flexible enough to allow for innovation, and be established through the regulatory process. Risk-sharing requirements should also be consistent with the goals of competition and broad community access.

\section{Appropriately-sized Investment Portfolios}

One cannot return to the days when the country's housing finance needs were supported through deposits alone. As a result, any reform should support the continued securitization of conventional mortgages. At the same time, the accumulation of implicitly subsidized large investments portfolios should be avoided, since the accompanying interest rate risk appears to outweigh the potential benefits of such investments. In general, the portfolio holdings of the GSEs (or their successors) should be closely regulated: the GSEs should be required to back their portfolios with more robust capital ratios, and should be required to pay the market price of risk when they borrow in order to own mortgages in portfolio. To the extent that the market continues to perceive an implicit guarantee, a tax on GSE debt could accomplish this end.

\section{Appropriate Affordable Housing Goals}

The Affordable Housing Goals also need to be reconsidered. Volume-oriented targets clearly did not work, and may have done more harm than good. At a minimum, the goals established for the GSEs should be consistent with the requirements imposed on the primary market. If subsidies are desired, such subsidies should be made explicit, and funded through the activities of the GSEs or the broader mortgage market. Presumably, making the subsidies more explicit would improve the allocation of scarce resources, and lead to better public policy. 


\section{Special Consideration for Multifamily Housing}

Finally, any reform proposal must ensure the continued support of rental housing, which remains the only viable option for many low- and moderate income families. This could be done by establishing a specialized conduit or removing portfolio limits on mortgages and securities collateralized by multifamily properties. Since multifamily mortgages are less suitable for securitization, the GSEs have retained most of their multifamily purchases in their investment portfolios. Any reform must recognize the importance of such investments, and support them going forward.

\section{Alternative Models}

At the moment, there are several leading options for GSE reform, although they are not mutually exclusive.

\section{Reconstituted GSEs}

The first option would preserve most of Fannie Mae and Freddie Mac, but with stronger oversight, limited portfolio authorities, and an explicit guarantee. The GSE model actually worked quite well for many years, and its contribution to systemic risk was relatively negligible. This began to change in the late 1990s, when both Fannie Mae and Freddie Mac accelerated the growth in their retained portfolios, extended their investments to private label MBS, and eventually lowered their underwriting standards.

However, in order for the GSE structure to work again, a couple of geniis will need to return to their bottles. One genii, of course, can never be returned: "implicit" guarantees are gone for awhile, if not forever. As a result, the government guarantee should become explicit. Opinions differ on whether this guarantee should be applied to the GSEs' debt, their MBS, or both. However, in our view, restricting the guarantee to their MBS would help to reduce the moral hazard that is associated with the current approach.

The GSEs should also return to their original focus on "prime" mortgages, i.e., loans to borrowers with an ability to support the payments, loans that are fully documented, and loans that are credit-enhanced if borrowers' equity is relatively low. While the GSEs are currently experiencing elevated losses on such "traditional" mortgages, these losses are not the reason the GSEs failed. In addition, once the current crisis passes, the GSEs portfolio holdings should be reduced dramatically. This could be done in several ways, for example, by establishing ceilings on their investment holdings, increasing their capital requirements, taxing their newly issued debt, or transferring some of their current assets to another entity (i.e., the "bad bank" approach.)

\section{Mortgage Conduit with Regulated Rate of Return}

A second option that would continue with the concept of private ownership would be to create a single mortgage conduit with a regulated rate of return and standardized pricing and product 
offerings. One could certainly make a case that a mortgage conduit is a natural monopoly since its fixed costs are relatively high and its marginal costs are more or less constant. In this sense, it is very similar to a power utility, and could conceivably be regulated in a similar way. In the case of a mortgage conduit, the regulator would have to establish a guarantee fee that results in an acceptable, but not excessive rate of return, but at the same time, encourages the conduit to engage in practices that meet market needs and minimize costs to borrowers.

Having a single mortgage utility could certainly help to level the playing field for small originators since guarantee fees would be set by the regulator and not negotiated as they are today. As a result, adopting such an approach could help to counter the growing concentration in the mortgage market. A single mortgage conduit could also avoid the kind of destructive competitive behavior that some believe led to a "race to the bottom" by Fannie Mae and Freddie Mac.

However, there are a number of challenges in implementing such an approach. To begin with, since guarantee fees are based on expected (as opposed to actual) default costs, a "reasonable" rate of return must be established on an ex ante basis. The fact that default costs are linked to the conduit's underwriting standards creates an additional regulatory challenge since it effectively requires the regulator to become a partner in setting those standards. As a result, a regulated returns model would probably only work for highly standardized mortgage products. Finally, since returns are limited, shareholders and management would have little, if anything, to gain from efficiencies and innovation. The challenge would be to design a regulatory structure that minimizes such effects through an appropriate set of incentives.

\section{Cooperative Model}

A third option would be to establish one or more mortgage "cooperatives" that would be owned by a consortium(s) of lenders. This model is not a new one. When Freddie Mac was created in 1970, it was a cooperative owned by the Federal Home Loan Banks and later, individual S\&Ls. The Federal Home Loan Bank System is also essentially a cooperative, since the customers of the FHLBs--banks and savings and loans--are also its shareholders. While the FHLBs primarily support portfolio lending, their authorities could be expanded to included securitization, or a newly created mortgage cooperative could be formed similar to the original Freddie Mac design.

Proponents of the Federal Home Loan Banks have argued that the model has provided capital stability and a critical source of market liquidity. However, others observers are less sanguine, noting that the joint and several liability feature of the FHLBs creates a serious moral hazard. Recent events have certainly shown that the FHLBs have not been immune from getting into trouble. In addition, because money is fungible, banks can use FHLB advances for a variety of non-housing purposes--including hiding capital short-falls. However, perhaps the greatest problem with the FHLB model relates to its capital structure. While member banks are required to purchase equity in the FHLB, their holdings are counted as tier-I capital. Since banks are 
highly levered, it is not at all clear that the system has sufficient capital in place to protect it from the potential failure of its members.

There are also problems associated with the governance structure of a cooperative. Multiple stakeholders can prevent timely and effective decision-making, and limit the entity's ability to respond to market forces. A cooperative can also be "captured” by its larger members, which could conceivably lead to suboptimal results.

\section{Covered Bonds}

A fourth option would be to adopt a "covered bond" approach similar to that employed in many European countries. Under this model, lenders would issue bonds that are collateralized by mortgages held in their investment portfolios. In EU countries, the issuance of mortgage covered bonds is regulated by laws that define the criteria for eligible assets, as well as various other requirements regarding credit enhancements and over-collateralization. To improve the bonds' attractiveness to investors and provide a more stable source of funding, the bonds could carry an FDIC-like guarantee that would protect investors in the event of issuer default. In exchange for this guarantee, the lender could pay an appropriate fee that would ultimately be reflected in the mortgage rate.

Covered bonds have worked relatively well for funding mortgages in Germany, Spain and Denmark. However, only Denmark has long-term fixed rate mortgages with an effective mechanism for prepayment. While it is not entirely clear why this is the case, it indicates a potential limitation with this approach. The more serious problem relates to the fact that the covered pool remains on the balance sheet of the issuer (i.e., the bank.) Thus, unlike a securitization model, covered bonds do not relieve the issuer of the need to hold capital against the credit risk, which effectively limits participation to well-capitalized banks. In our view, the benefits that would be derived from such an approach would not be as great as those produced by securitization.

\section{Multiple Conduits with Single Guaranteed Security}

A fifth option would support a securitization model through the issuance of guaranteed MBS. While there are many ways to structure such a model, one approach would be to create a relatively small number of federally-chartered mortgage conduits, which would acquire loans in the primary market and deliver them to a common issuer for pooling and securitization. The resulting securities would be guaranteed by an FDIC-like entity in exchange for an appropriate fee. The federal guarantee would be analogous to a Ginnie Mae “wrap,” and ensure the timely payment of principal and interest on the bonds. However, the credit risk on the underlying mortgages would continue to be held by the mortgage conduits.

This approach has a number of distinct advantages. Since mortgages would be delivered to a common issuer for securitization, the model could accommodate multiple GSEs without 
jeopardizing the liquidity of the underlying securities. In addition, since the mortgage-backed securities would not be issued in the conduit's name, the systemic risk associated with a conduit's failure would be lower than is for Fannie Mae and Freddie Mac, particularly if multiple conduits are involved. Finally, since the conduits' debt (and other obligations) would not be guaranteed, the moral hazard inherent in the GSE approach would be reduced. Although systemic risk and moral hazard would probably not disappear-indeed, any large financial institution may now be deemed too big to fail--such a structure could help to address some of the fundamental weaknesses of the GSE model while retaining most of its advantages.

One of the issues that would have to be resolved is the extent to which the conduits should be allowed to hold investment portfolios. At a minimum, limited portfolio authority would be required for operational and pooling purposes, and to ensure that small originators can continue to deliver mortgages on a loan-by-loan basis. In addition, since securitization is less appropriate for multifamily mortgages, provisions would have to be made to ensure a reliable secondary market outlet for such loans, for example, by creating a specialized conduit, exempting multifamily mortgages from portfolio limits, or subsidizing the fee for the government wrap. Finally, limiting the GSEs' activities to the securitization side of the business could lead to higher mortgage rates. If the GSEs no longer had their investment portfolios as a major earnings source, guarantee fees might have to rise to provide an adequate return to the conduits' investors.

\section{Conclusions}

The different options described above all have distinct advantages and disadvantages. Even if one accepts a given approach, there are numerous variants on each approach, each involving important policy issues. There are also thorny issues related to the restructuring (or dissolution) of Fannie Mae and Freddie Mac and how to handle their outstanding securities. Some have proposed splitting the Agencies into a "good bank" and a "bad bank," while others believe that the magnitude of their current losses would preclude a strategy of this kind. Regardless of what happens, parts of Fannie Mae and Freddie Mac are likely to survive, and provide at least some of the basic infrastructure for their replacements.

In the end, whatever approach is selected should be driven by the same basic policy objectives that led to the creation the GSEs, namely, to ensure a stable and liquid secondary mortgage market that promotes widespread access to affordable housing finance. While the solution might differ, these objectives are as relevant today as they were four decades ago, when Fannie Mae and Freddie Mac were first charged with creating a viable secondary market for conventional mortgages. 


\section{I.0 Introduction}

Not so long ago, the US housing finance system was arguably the best in the world. Consumers had access to products-most notably, the 30 year fixed rate, freely pre-payable mortgage--that were not available elsewhere, and the market was able to sustain major economic disruptionsincluding the 1998 financial crisis and the 911 terrorist attack-with relatively little impact on either the cost or availability of mortgage credit. Fannie Mae and Freddie Mac (hereafter the $\mathrm{GSEs}^{2}$ ) provided the cornerstone of the mortgage market and deserve much of the credit for its success.

Despite their many accomplishments, the two government sponsored enterprises (GSEs) have fallen into widespread disfavor as a result of perceived abuses of market power, accounting scandals, deteriorating underwriting standards, and ultimately, the need for government conservatorship. Most academics and policymakers have now concluded that their quasigovernmental model is no longer viable and that an alternative structure must be devised. ${ }^{3}$ Viewed in terms of a continuum of government involvement ranging from "purely private" to "purely public," the "purely public" solution seems to be winning out.

In our view, however, much would be lost if one moved to either end of the support continuum. The purely private model has clearly failed in the past two years. Almost no mortgage lending occurs today without the implicit or explicit backing of the federal government, and private institutions that once competed with the Fannie Mae and Freddie Mac have either failed or are now reliant on government funding. Even before the financial crisis, Freddie Mac's former Chief Economist, Robert Van Order, argued that banks' reliance on FDIC insurance made them another form of GSE. These similarities are more apparent than ever today. In the end, there is relatively little difference between the government's treatment of Fannie Mae and Freddie Mac and its treatment of private companies such as Citigroup and AIG that were deemed too big to fail.

At the same time, it is difficult to argue that a purely government approach would be a good alternative to Fannie Mae and Freddie Mac. FHA's ability to serve the market has long been hampered by management, political and resource constraints. The current crisis, which has generated an explosive growth in FHA lending, has further contributed to these problems.

\footnotetext{
${ }^{2}$ In this paper, for ease of exposition, we use the term GSE to refer only to Fannie Mae and Freddie Mac. Our comments do not include references to the Federal Home Loan Banks, which are another form of GSEs.

${ }^{3}$ See, for example, Dwight Jaffee and John Quigley (2007) Housing Subsidies and Homeowners: What Role for Government Sponsored Enterprises? University of California-Berkeley working paper. Access at http://elsa.berkeley.edu/users/quigley/pdf/JQ_Housing_Subsidies_Proof_053007.pdf. August 12, 2009.
} 
FHA's regulatory capital is rapidly running out, ${ }^{4}$ and a recent report by HUD's Inspector General cites numerous examples of the Agency's lax underwriting standards, failure to monitor lenders, and vulnerability to fraud. ${ }^{5}$ Even if "reformed", it is doubtful that FHA could ever produce the range of benefits heretofore provided by the GSEs.

This paper attempts to establish a case for GSE reform that retains a market-driven approach but addresses acknowledged problems through better regulation and charter revisions. Our core assumption is that reform is possible without abandoning key aspects of the original GSE model, including access to a government guarantee and a reliance on profit incentives to set priorities and allocate resources.

Section 2 describes the basic business model that Fannie Mae and Freddie Mac have used for the past two decades. Section 3 presents a brief history of the rise and eventual fall of the GSEs. Section 4 discusses the benefits that have been produced by the GSE model, as well as its major drawbacks. Section 5 proposes several overarching principles that should be the basis of any reform, and Section 6 evaluates several alternative models on the basis of these principles. Although our analysis inevitably reflects our own opinions and experiences, we have drawn on empirical evidence whenever possible to develop and support our case.

\subsection{How Fannie Mae and Freddie Mac Support the Mortgage Market}

Fannie Mae and Freddie Mac have two basic lines of business: a mortgage "guarantee" business and a mortgage portfolio, or "investment" business. Both activities help to support a secondary market for residential mortgages.

The guarantee side of the business involves the securitization of mortgages. This includes purchasing mortgages from loan originators, bundling the mortgages into mortgage-backed securities (MBS), and selling the resulting securities to other investors through Wall Street firms. Fannie Mae and Freddie Mac assume the underlying credit risk on the mortgages that they securitize and are responsible for any losses that occur when a loan defaults. The fee that they charge for such insurance is known as the "guarantee fee." Profits are earned by charging a guarantee fee that is sufficient to cover the losses arising from default, as well as the associated administrative and capital costs.

The investment side of the GSEs' business involves their retained mortgage portfolios, which include both individual mortgages ("whole loans") as well as MBS and other types of assetbacked securities (ABS.) While Fannie Mae and Freddie Mac retain some of the individual

\footnotetext{
${ }^{4}$ See Michael Goldberg and Ann B. Schnare, “A Financial Analysis of the FHA Insurance Fund,” November 2008, and “An Updated Look at the FHA Fund,” January 2009.

5 “FHA, HUD Fraud Prevention, Statement of Kenneth M. Donohue, Inspector General, US Department of Housing and Urban Development”, June 18, 2009.
} 
mortgages they acquire from loan originators, their primary holdings consist of MBS (or ABS) that are purchased in the capital market. The GSEs fund their mortgage holdings through the issuance of corporate debt. Profits from such activities are generated from the difference between the interest earned from their mortgage holdings and their funding and hedging costs.

There are four types of risks that are generally associated with Fannie Mae's and Freddie Mac's business: credit risk, interest rate risk, market risk, and management risk.

- Credit risk arises from mortgage default. In general, it reflects both the probability that the borrower will default as well as the losses incurred upon default (i.e., the "loss severity" rate.)

- Interest rate risk arises from a change in interest rates. Since mortgages are fully prepayable, declining rates will cause the security to prepay at a faster rate, forcing the investor to reinvest the proceeds at a lower rate. Rising rates will have the opposite effect.

- Market risk arises from external events that affect their major lines of business, for example, a decline in market demand that reduces the value of their portfolio holdings. Since securities have to be marked-to-market on a regular basis, any change in their market value will have an immediate impact on the GSEs' balance sheets.

- Management (or operational risk) stems from operational breakdowns, or errors, that can affect a company's earnings.

While all of the GSEs' activities are susceptible to management risk, the risks associated with the guarantee and investment sides of their two business lines are distinctly different.

The guarantee (or securitization) side of their businesses primarily exposes the companies to credit risk, i.e., the risk that the loans will default. Since the MBS are sold into the capital market, the security's investors - as opposed to the GSEs--assume the "interest rate" risk. To manage their credit risk, the GSEs establish underwriting guidelines for the loans they are willing to buy, and conduct on-going quality control reviews to ensure that lenders are following the established guidelines. Loans that fail to meet established guidelines are subject to repurchase.

In contrast, the investment side of the business primarily exposes the GSEs to interest rate risk. Interest rate risk is managed through a variety of means, for example, by matching the maturity of the debt with the projected life of the loans or by purchasing an interest-rate hedge. Traditionally, most of the GSEs' mortgages holdings have consisted of their own securities (or other forms of guaranteed MBS.) As a result, their investment portfolios did not expose them to 
additional credit risk. However, this has changed in recent years, since both agencies invested heavily in "private label” MBS and other types of asset-backed securities. ${ }^{6}$

While the bulk of the GSEs' activities involve single family residential mortgages, they also play an important role in financing multifamily housing. The majority of multifamily loans that are purchased by Fannie Mae and Freddie Mac are funded through their investment portfolios. Given the heterogeneous nature of multifamily mortgages, multifamily mortgages are less suitable for securitization. As a result, while both GSEs have issued a certain amount of Multifamily MBS over the years, the volume has typically been relatively low in comparison to their annual purchases of multifamily loans. ${ }^{7}$

\subsection{A Brief History of Fannie Mae and Freddie Mac}

Fannie Mae and Freddie Mac were established to create a liquid and stable market for residential mortgages. Although their histories and original mandates differed, both companies were given substantially identical charters with the passage of the Financial Institutions Reform Recovery and Enforcement Act (FIRREA) in 1989. As shareholder-owned, federally-chartered entities with a public purpose and special privileges, Fannie Mae and Freddie Mac became increasingly dominant forces in the mortgage market over the ensuing years.

Fannie Mae was established as a federal agency in 1938 to provide a secondary market for FHA (and, shortly thereafter, VA) loans. Fannie Mae operated as an independent government agency for next 30 years, but was restructured as a shareholder-owned corporation in 1968, largely to remove its liabilities from the federal government's books in the face of mounting deficits from the Vietnam War. At the same time, Fannie Mae's mandate was expanded to include the purchase of conventional mortgages and a new government agency was formed--the Government National Mortgage Association, or Ginnie Mae. Ginnie Mae, which became part of the newly created U.S. Department of Housing and Urban Development, established a securitization vehicle for securities backed by government-insured loans by guaranteeing the timely payment of interest and principle. The first Ginnie Mae security was issued in 1970.

Freddie Mac was created in the same year to provide a competitor for Fannie Mae and to further support a secondary market for conventional loans. While originally owned by the Federal Home Loan Banks, Freddie Mac issued 15 million shares of non-voting stock to member thrifts in 1984, effectively becoming an industry-owned cooperative. Freddie Mac was transformed into a shareholder-owned company five years later following the passage of FIRREA. In fact,

\footnotetext{
${ }^{6}$ Since their security holdings are required to be marked-to-market, these investments also exposed the GSEs to massive write-offs following the collapse of the subprime market. Whether or not these write-offs are accurate reflections of the losses that will ultimately be incurred is difficult to determine at this stage.

${ }^{7}$ See 2008 Annual Report, Federal Housing Finance Agency, Tables 1, 2, 10, and 11.
} 
the proceeds from its sale helped offset the massive losses experienced by the thrifts as a result of the S\&L crisis in the late 1980s.

For purposes of this discussion, we have divided the histories of Fannie Mae and Freddie Mac from 1970 into five distinct periods: 1970 through 1989, which began with privatization of Fannie Mae and the creation of Freddie Mac and ended with the passage of FIRREA; 1990 through 1998, when Fannie Mae and Freddie Mac came into their own as shareholder-owned companies and began to consolidate their market power; 1998 to 2003, which witnessed the explosive growth of the two companies and their increasing market dominance; 2004 through mid-2007, which saw the ascendance of private conduits and the explosion of subprime lending; and mid-2007 through today, which encompassed the meltdown of the private mortgage market, the creation of a new regulatory agency--the Federal Housing Finance Agency (FHFA)--and the government takeover of both Fannie Mae and Freddie Mac.

\subsection{The Formative Years: 1970 to 1989}

Most of the GSEs' activities in these early years involved establishing the basic infrastructure required to support a robust secondary mortgage market for conventional mortgages. One of their first and most important accomplishments was to standardize the origination and underwriting process. At the time, conventional underwriting guidelines varied from lender to lender, as did application procedures, documentation requirements, and closing and servicing protocols. In order to facilitate the development of a secondary market for these loans, Fannie Mae and Freddie Mac had to develop a wide array of standardized forms and legal documents that governed the closing, funding and subsequent sale of any loan. They also developed a comprehensive set of underwriting guidelines that specified the terms and conditions of the loans they would buy. Such standardization enabled otherwise heterogeneous loans to be pooled and transformed into mortgage-backed securities without requiring detailed reviews of each underlying loan.

Other major milestones of this period involved the development and refinement of conventional mortgage-backed securities. In 1971, Freddie Mac issued the first conventional mortgagebacked security, known as the Mortgage Participation Certificate, or PC. Like the original Ginnie Mae securities, PCs were mortgage “pass-throughs,” i.e., they distributed the cash flows from a mortgage pool on a simple pro rata basis. Owing to the long duration of many mortgages, these instruments primarily appealed to long-term investors. Twelve years later, Freddie Mac greatly expanded the pool of potential investors by issuing the first Collateralized Mortgage Obligation, or CMO. Unlike a mortgage pass-through, a CMO structures the cash flows from a mortgage pool into separate bonds, or tranches, with different payment schedules. By creating bonds with shorter durations, this innovation significantly broadened the market for mortgagebacked securities. 
In contrast to Freddie Mac, Fannie Mae continued to hold most of its mortgages on its books in these early years, following the approach it had used since its creation in 1938. As interest rates moved into double-digit territory in the mid-to late 1970s, Fannie Mae's practice of funding long-term mortgages with short-term debt put it in the same precarious position as many S\&Ls. By 1981 Fannie Mae was technically insolvent as its interest payments exceeded its interest costs, so the present value of its assets were less than the present value of its liabilities. ${ }^{8}$ While it was able to survive largely as a result of its government ties, Fannie Mae remained in a weakened financial condition until 1985, when interest rates finally dropped from their historic highs.

Fannie Mae issued its first mortgage-backed security, or MBS, in 1981. Like Freddie Mac's Participation Certificates, Fannie Mae MBS were mortgage pass-throughs. Fannie Mae issued its first structured security in 1987 in the form of a Real Estate Mortgage Investment Conduit, or REMIC. Although the legal structure of a REMIC is different from a CMO, they are similar in their treatment of cash flows from a mortgage pool. While somewhat late to the securitization game, Fannie Mae entered the MBS market aggressively. By the end of the decade, Fannie Mae issuances of mortgage-backed securities exceeded those of Freddie Mac. ${ }^{9}$

The period came to an end with the passage of FIRREA, which changed the ownership structure of Freddie Mac into a shareholder-owned company with a charter comparable to that of Fannie Mae. By the time that FIRREA was passed, the securitization market for conventional mortgages was well-established and comparatively large. The GSEs' issuances of mortgagebacked securities (i.e., PCs and MBS) totaled about \$170.5 billion in 1990, up from just \$62.4 billion five years earlier. ${ }^{10}$ Issuances of GSE multiclass securities (i.e., CMO/REMIC) were at $\$ 111.7$ billion. By 1990, the total volume of outstanding GSE-backed securities was over \$611.0 billion, fifty percent higher than GNMA MBS (\$401 million.) ${ }^{11}$ While there was a small emerging market for private-label securities, the outstanding volume of non-agency MBS was just $\$ 55$ billion in that year.

\subsection{The Golden Years: 1990 to 2003}

For Fannie Mae and Freddie Mac, the thirteen year period following the passage of FIRREA can generally be characterized as one of consolidation and market innovation, followed by explosive growth and increasing market power.

\footnotetext{
${ }^{8}$ See http://www.fhfa.gov/webfiles/2335/FHFA_ReportToCongress2008508.pdf, page 110. Accessed August 12, 2009.

${ }^{9}$ Inside Mortgage Finance, Mortgage Yearbook for 2007, p.21

${ }^{10}$ Ibid, , p.21

${ }^{11}$ Ibid, p. 33. Calculations exclude CMO/REMIC to avoid double-counting.
} 
Both GSEs emerged from FIRREA in positions of strength. Fannie Mae had largely recovered from its near financial collapse, and Freddie Mac had been transformed from an industrycontrolled co-operative into a shareholder-owned firm. As a result, both companies were poised to take advantages of the special privileges provided by their federal charters. These included a $\$ 2.5$ billion line of credit with the US Treasury, exemptions from SEC registration requirements and state and local income taxes, and the classification of the GSEs' securities as "Tier 1" capital for reserving purposes. Since these charter privileges were generally interpreted as "implicit" guarantees on the part of the US government, the GSEs' debt and securities traded at favorable rates, making it difficult for other entities to compete.

The regulatory framework that would govern the companies for the next 15 years was put into place in 1992 with the passage of The Federal Housing Enterprise Financial Safety and Soundness Act (FHEFSSA.) The legislation established a dedicated federal regulator-known as the Office of Federal Housing Enterprise Oversight, or OFHEO-and called for the development of risk-based capital standards and Affordable Housing Goals. While risk-based capital standards were designed to be an alternative to minimum capital requirements, for a variety of reasons, they proved to be less binding than the capital standards already in place. The net effect was that both GSEs were able to leverage their capital to a high degree in order to support their rapidly growing guarantee and investment activities.

\section{Growing Market Share}

The GSEs guarantee business grew dramatically over the thirteen year period. Their combined market share (defined as the ratio of their new single-family business to total originations) rose from about 41.5 percent of the overall market in 1990 to 57.0 percent in 2003. (See Exhibit 1.) Excluding jumbo mortgages, their overall market share went from 54.4 to 73.2 percent. Over the same period of time, the outstanding volume of mortgage-backed securities issued by the GSEs (i.e., PCs and MBS) more than quadrupled, from about \$610 billion in 1990 to some \$2.8 trillion in 2003. (See Exhibit 2.)

The investment-side of the GSEs' businesses also grew dramatically, particularly between 1998 and 2003. (See Exhibit 3.) Freddie Mac did not hold a mortgage portfolio until the early 1990s, and the initial growth of its holdings was relatively slow. However, from 1998 to 2003, Freddie Mac's retained portfolio grew at an annual average rate of about 21 percent. Over the same period of time, Fannie Mae's mortgage holdings increased by an annual average rate of 17 percent. By 2003, Freddie Mac’s retained portfolio (\$661 billion) was about 72 percent as large as Fannie Mae’s (\$920 billion.)

The high rate of growth of the GSEs' retained portfolios from 1998 to 2003 reflected a variety of factors, including pressures on their guarantee fees. However, the collapse of the Russian bond market and Long Term Capital in 1998 provided the GSEs with a rare opportunity. On the one hand, the rising spreads that resulted from the turmoil in global financial markets made their 
portfolio investments extremely profitable; as investors fled to quality, the GSEs' comparative funding advantage increased. At the same time, the GSEs' investment and securitization activities helped to ensure a steady flow of mortgage credit, a clear demonstration of their public purpose. This win-win situation gave Fannie Mae and Freddie Mac considerable political cover as they locked-in long term profits. The problem, as we now know, is that the GSEs held insufficient capital; their implicit debt subsidy also encouraged them to finance their portfolios with excessive debt.

But even after the crisis passed, both GSEs continued to grow their portfolios at a rapid rate, reflecting the high rates of return that were being generated through this side of their businesses. The nature of their mortgage holdings also began to change. Prior to 1997, Fannie Mae and Freddie Mac primarily invested in whole loans and MBS whose performance was wellunderstood and guaranteed. In most instances, they purchased their own securities or retained loans acquired through the guarantee side of their business. ${ }^{12}$ However, after this time, both GSEs began to acquire significant volumes of private-label asset-backed securities (ABS), which introduced a new layer of credit risk into their traditional portfolio holdings.

Private label securities represented roughly seven percent of Fannie Mae's aggregate mortgagerelated purchases from 1998 through 2003, up from zero in the early 1990s. (See Exhibit 4.) The figures for Freddie Mac show a more aggressive entry into this market, with private label securities averaging around 15 percent of its purchases over this period (i.e., 1998 through 2003.). While more detailed breakdowns of the GSEs' purchases are not available until 2002 or later $^{13}$, their private label purchases evidently began with commercial mortgage-backed securities (CMBS) but later extended to include large numbers of securities backed by subprime and Alt-A loans.

By 2003, Fannie Mae and Freddie Mac’s total debt outstanding stood at \$1.7 trillion, or about 25 percent of total US Treasuries (\$6.8 trillion). (See Exhibit 5.) The total volume of the GSEs' outstanding mortgage-backed securities was $\$ 4.4$ trillion. Not only had Fannie Mae and Freddie Mac become the dominant players in the US mortgage industry, their securities and debt had become intrinsic parts of the global capital market. Indeed, in the late 1990s, when the country was experiencing a budget surplus, there was even some talk that Fannie Mae and Freddie Mac debt would become the new global benchmark.

Not surprisingly, both Fannie Mae and Freddie Mac were the darlings of Wall Street throughout much of this period. Both companies reported double-digit earnings growth year after year, with only one exception. And the stock of both companies soared, enriching management and

\footnotetext{
${ }^{12}$ Both agencies also purchased limited amounts of Ginnie Mae securities, as well as securities issued by the other agency. See Table 1b and 10b, Part 1. Federal Housing Finance Agency 2008 Annual Report.

${ }^{13}$ Fannie Mae data is available beginning in 2002. Freddie Mac data begins in 2006. See Table $1 \mathrm{~b}$ and $10 \mathrm{~b}$ from the Federal Housing Finance Agency 2008 Annual Report.
} 
shareholders alike. Most of the gains occurred between 1990 and 1999, when Fannie Mae and Freddie Mac share prices rose by 722 and 992 percent, respectively. ${ }^{14}$ (See Exhibit 6.)

\section{Introduction of Automated Underwriting}

The rapid growth of the Agencies was accompanied by dramatic improvements in their ability to measure and manage their credit risk. Freddie Mac's introduction of credit scores to the underwriting process in 1996 had a revolutionary effect on the mortgage market. While initially resisted by the industry and many consumer groups, the use of credit scores rapidly became the norm, and is now an integral part of most lenders' underwriting, servicing, and risk management procedures.

The GSEs' concurrent development of automated underwriting systems (AUS) in the late 1990s also dramatically improved the loan origination process by making it faster, less expensive, and arguably fairer. One study by Freddie Mac found that moving from a manual to automated system expanded the market by increasing the number of qualified borrowers. ${ }^{15}$ Whether or not one accepts the broader applicability of these results, the GSEs' efforts to improve the underwriting process were clearly cutting edge and undoubtedly enhanced the industry's understanding of credit risk. ${ }^{16}$ It also dramatically increased both the ability of both the industry and the GSEs to handle the large volumes of loans that accompanied the refinancing booms of 1998 and 2002-2003.

Along with automated underwriting models, the GSEs developed automated capital allocation models, whose purpose was to map risks to prices. In principle, the GSES could decide to purchase riskier mortgage in exchange for charging higher guarantee fees when the mortgages became securitized. It is not clear to us, however, whether the GSEs' risk was the principal determination of how they negotiated fees. Customer relationships likely had a large impact on the size of fees they charged.

However, some have argued that the movement to AUS, and the GSEs' dominance in this area, came at a cost-namely, that as the industry generally moved away from traditional underwriting and placed greater reliance on computerized scoring models, it helped to set the stage for the subsequent deterioration in underwriting standards. Looking back, this argument has some appeal. It is certainly the case that one of the drivers of the subprime crisis was the wholesale abandonment of underwriting standards and protocols that the GSEs had helped to develop and had previously imposed on the market place. It is also the case that as the housing

\footnotetext{
${ }^{14}$ Calculations based on change between January 5, 1990 and January 1, 1999.

${ }^{15}$ Susan Gates, et. al, “Automated Underwriting: Friend or Foe to Low - Mod Households and Neighborhoods? Building Assets, Building Credit: A Symposium on Improving Financial Services in Low-Income Communities, November 18-19, 2003

${ }^{16}$ In a risk adverse environment such as today, more precision in underwriting should increase acceptance rates.
} 
market began to turn, scoring models based on more favorable economic conditions failed to perform.

\section{Accounting Scandals}

By the end of the 1990s, the growing market dominance of the GSEs was met with rising concerns among federal regulators and both the Clinton and Bush Administrations that the GSEs had become "too big to fail". Much of this concern surrounded the size of their investment portfolios and their exposure to interest rate risk. While both the Federal Reserve and the Treasury Department made numerous attempts to limit their investment holdings, these were invariably thwarted by sympathetic members of Congress from both sides of the aisle. ${ }^{17}$

Concerns over the potential exposure of the federal government were further heightened by separate accounting scandals that resulted in the ouster of senior management at both companies in 2003 and 2004. The problems began at Freddie Mac in the wake of the Enron scandal, which forced the company to replace its long-time auditor, Arthur Anderson. The new auditor concluded that certain accounting treatments in previous years had understated corporate earnings by about $\$ 5$ billion. These findings ultimately led to ouster of Freddie Mac's long-time CEO and President in June 2003.

A similar scandal and management upheaval transpired a year and a half later at Fannie Mae. While the details are very different-Fannie Mae management was accused of overstating its earnings by $\$ 9$ billion in order to maximize executive bonuses- the net results were essentially the same. Members of Fannie Mae senior management, including its CEO, were forced to resign in December 2004, and a new executive team was formed.

Some observers believe that the resulting turmoil at the two companies helped to pave the way for the rise of the private conduits and the explosion of nontraditional mortgage products, including subprime lending. In any event, new management teams at both GSEs were forced to devote a considerable amount of their time and resources to the complex task of restating earnings at a time when the market was changing rapidly. Over the next three years, Fannie Mae and Freddie Mac found themselves in the unfamiliar position of having to compete with private conduits on both price and product.

\subsection{The Rise of Private Conduits and Subprime Lending: 2004 to Mid-2007}

The market dominance of Fannie Mae and Freddie Mac began to erode in 2004 as a result of dramatic shifts in both the mortgage and capital markets. Record low mortgage rates and rapidly escalating housing prices triggered a massive refinancing boom in 2002 and 2003 that was followed by a 26 percent decline in originations in 2004. This decline was arrested in the

\footnotetext{
${ }^{17}$ For a more detailed discussion, see Bethany McLean, “The Fall of Fannie Mae,” Fortune Magazine, January 24, 2005.
} 
following year by a dramatic increase in the origination of subprime mortgages and other nontraditional products such as "low doc" loans and "pay option ARMs" (collectively known as "Alt-A product"). The origination of subprime and Alt-A mortgages increased dramatically from 2005 through mid-2007, accounting for as much as 34 percent of the overall market. (See Exhibit 7.) Most of these mortgages were packaged into private label securities and sold through Wall Street firms.

The underlying causes of these developments are well known and thoroughly documented, and stemmed from a deadly combination of rapidly accelerating housing prices, a global excess of capital, deteriorating underwriting standards, a private securitization model where the various entities involved in the transaction had little capital at risk, and an increased reliance on highly complex, financially-engineered products to manage the credit risk. The net result was to shift the mortgage market away from the relatively conservative and standardized underwriting practices that had been promulgated by the GSEs in favor of the significantly looser standards.

The decline in the relative importance of conventional, conforming mortgages-and the concurrent growth of subprime and Alt-A lending — had a dramatic impact on the guarantee side of the GSEs' businesses. In 2003, Fannie Mae and Freddie Mac accounted for roughly 71 percent of all single-family securitizations. By mid-2007, their share had dropped to 49 percent. (See Exhibit 8.) Over the same period of time, the share of private-label securities backed by subprime and Alt-A loans increased from 46 to 68 percent. This development placed the GSEs in a difficult position - either they could accept a smaller, less profitable guarantee business or expand into these markets as well. Unfortunately, both companies chose the latter path.

At the same time, both Fannie Mae and Freddie Mac reduced their underwriting standards for their mainstream business by introducing "expanded" versions of their automated underwriting systems, DU and Loan Prospector. While essentially "black boxes" to the rest of the industry, the net result of these modifications-labeled "expanded authority" by Fannie Mae--was to expand the boundaries of conventional lending into territory previously occupied by subprime loans. Based on the recent performance of conventional loans insured by Genworth, subsequent versions of Fannie Mae's "Expanded Authority" program have led to increasingly higher rates of defaults.

Pressures on the guarantee side of the business were also accompanied by a dramatic slowdown in the growth of the GSEs' retained portfolios, their primary engines for earnings growth. Indeed, growth in their combined portfolios came to an end in 2004, and then began to decline. Several factors contributed to this development, including the 30 percent capital surcharge that OFHEO imposed in the wake of the companies' accounting scandals. More fundamentally, however, the market conditions that caused the explosion of subprime lending also affected the GSEs' comparative advantage on the investment side of their businesses by reducing the spreads they could earn on conventional mortgage-backed securities. 
Like other investors at the time, both Fannie Mae and Freddie Mac became active investors in subprime securities in an effort to achieve higher yields and, some would assert, to meet their mandated affordable housing goals. Private label securities accounted for 56 percent of Fannie Mae's total mortgage-related security purchases from 2004 through 2006, and 54 percent for Freddie Mac. (See Exhibit 4.) Most of these purchases involved securities backed by subprime or Alt-A mortgages. (See Exhibit 9.) In 2006, the GSEs' purchases of such securities represented 9.8 percent of the total volume of subprime and Alt-A originations made within the year.

\subsection{The Beginning of the End: Late-2007 to the Present}

The mortgage market began to change again in mid- to late 2006, when rising delinquencies on subprime mortgages and the cooling of the housing market began to affect the financial health of many subprime lenders. Monthly failures of subprime loan originators began to rise at the end of 2006. By August 2007, when the situation reached crisis proportions, more than 100 subprime lenders had shut their doors. (See Exhibit 10.) After that point, the volume of subprime lending went into a virtual freefall, falling to less than 3 percent of the overall market by the end of 2007.

While the decline in the Alt-A market began somewhat later than it did for subprime loans, August 2007 also proved to be pivotal for this sector of the mortgage market. While Alt-A originations had been falling steadily in the first three quarters of 2007, originations dropped by 50 percent in the final quarter of the year. By the beginning of 2008, both the Alt-A and subprime markets had virtually disappeared. The securitization of jumbo mortgages also ground to a halt, leaving the mortgage market almost entirely in the hands of the GSEs and FHA.

Since late 2007, Fannie Mae and Freddie Mac have dominated the mortgage market as never before. The liquidity crisis that began in the subprime and Alt-A sectors subsequently spread to prime jumbo lending, and capital constraints have severely limited the ability of banks to portfolio loans. As a result of these developments, the Agencies' market share has risen to more than 72 percent of originations and 77 percent of all single-family MBS issuances. (See Exhibits 1 and 8.) While mortgage originations are up in 2009 due to record-low interest rates, most lending that occurs today are supported by the GSEs or FHA.

Unfortunately for Fannie Mae and Freddie Mac, the story does not end there. Until recently, the performance of conventional conforming mortgages has remained relatively strong. However, both Fannie Mae and Freddie Mac were exposed to the massive losses from other sectors of the mortgage market. This exposure came from two primary sources. First, both GSEs invested heavily in the triple-A tranches of subprime securities. Indeed, some critics contend that their large investments in such instruments helped to feed the explosive growth of subprime lending. The precipitous decline in the value of these securities, combined with mark-to-market accounting rules, forced both Fannie Mae and Freddie Mac to take massive write-offs at the end of 2007 and again in 2008. 
In addition, both companies purchased relatively large volumes of Alt-A mortgages in 2005 and 2006 in an apparent effort to bolster their declining market shares. The poor performance of these loans subsequently led to credit losses on the guarantee sides of the business. In 2008, for example, Alt-A mortgages represented just 9.7 percent of Fannie Mae’s book, but accounted for almost 40 percent of the company's credit losses. The experience at Freddie Mac tells a similar story: the serious delinquency rate on Freddie Mac's Alt-A book (which is 8 percent of the portfolio) is more than three times higher than the total portfolio's rate. ${ }^{18}$

As a result of these adverse developments, the net income of both GSEs fell into negative territory in 2007 and then imploded in 2008. (See Exhibit 11.) Their combined losses in 2008 (\$109 billion combined) were higher than the total profits earned by the two GSEs from 1990 through 2007 (\$95 billion).

Mounting financial pressures, along with concerns that the companies might not be able to refinance their maturing debt, ultimately led to their takeover by the federal government on September 7, 2008. Senior management teams were once again replaced. While some believe that the takeovers were at least in part politically motivated, the companies have since required about $\$ 60$ billion in funding from the US Treasury and the latest OMB estimates now predict that the total could be close to $\$ 200$ billion. At the same time, the Federal Reserve has had to purchase roughly $\$ 500$ billion in the GSEs' MBS in order to stabilize the value of their securities.

Ironically, while Fannie Mae and Freddie Mac are now essentially wards of the state, their importance to the mortgage market and overall economy has never been greater. Yet at the same time, most observers believe that their quasi-governmental model is effectively dead, if only because it would be difficult, if not impossible to return to the notion of an "implicit" guarantee. Before turning to some thoughts on alternative models, it is useful to take a critical look at the benefits that the GSEs have brought to the housing and mortgage markets, as well as their underlying weaknesses.

\subsection{The Benefits of the GSE Model}

In order to understand how one could improve upon the current model, one first needs to recognize the benefits that Freddie Mac and Fannie Mae have brought to the mortgage market. The two GSEs have identical charter objectives, namely, to:

- Create a liquid and reliable secondary market for residential mortgages;

- Respond appropriately to the needs of the capital market; and

\footnotetext{
${ }^{18}$ See Freddie Mac First Quarter 2009 Financial Results Supplement, May 12, 2009.
} 
- Improve the distribution of mortgage credit by promoting broader access to affordable mortgage finance.

While opinions differ with respect to the actual accomplishments of Fannie Mae and Freddie Mac, we have organized our discussion around the specific objectives that are embedded in their charters: standardization; liquidity; stability; and access to affordable mortgage finance. For each potential benefit, we discuss both the accomplishments of the GSEs, as well as the specific authorities or functions that were required to produce the results.

\subsection{Standardization}

As noted earlier, one of the first and most important accomplishments of the Fannie Mae and Freddie Mac was to standardize the origination, underwriting and securitization processes. Standardization served to commoditize residential mortgages, which created efficiencies and lowered costs.

For many years, Fannie Mae and Freddie Mac also set the standard for determining an "acceptable" level of credit risk. Their underwriting guidelines and protocols were used throughout the industry in assessing the underlying quality of any loan. While both GSEs abandoned their standards at the height of the subprime boom, they have resumed this role again today, albeit under the watchful eyes of their Federal regulator.

Whether or not the benefits of standardization could have been accomplished through other means is a matter for debate. In our view, there is nothing inherent in the GSE model per se that makes them particularly suited to play this role, other than their size and market dominance (which were clearly critical.) If one abandons the GSE model, this function could presumably be performed by a regulatory agency, the entity (or entities) that take their place, or even an industry consortium. However, in order to be effective and enforceable, standardization requires the entity creating the standards to have sufficient legal, regulatory or market clout to enforce compliance.

\subsection{Liquidity}

Mortgages, by very nature, are highly illiquid financial instruments. Not only are they "lumpy"- that is, if one wants to invest in a mortgage, one must purchase the entire amounttheir performance will differ with the underlying characteristics of the borrower, the property and the market. The time and expertise required to assess the likely performance of any loan makes them relatively unattractive investments for all but a handful of potential investors. As a result, while there was some inter-bank trading prior to the development of the secondary market, most institutions held the majority of the loans they originated for the entire life of the loans.

Fannie Mae and Freddie Mac created a liquid mortgage market by purchasing loans from mortgage originators and pooling the loans into mortgage backed securities. The pooling of loans 
served to diversify credit risk and enabled investors to purchase shares of the underlying mortgages, as opposed to the mortgages themselves. However, in addition to standardization, the key innovation was the "implicit" guarantee on the credit risk on the underlying loans. While investors continued to hold the interest rate risk, Fannie Mae and Freddie Mac guaranteed the credit losses in the event of mortgage default. Because of their special status as governmentsponsored entities, most investors believed that this guarantee was ultimately backed by the full faith and credit of the federal government (despite explicit statements to the contrary that appear on every issuance.) As a result, investors had little, if any need to conduct an independent assessment of the credit quality of the underlying loans.

Until the recent mortgage meltdown, private label securities were also able to achieve a relatively high degree of liquidity by structuring a security's cash flows into different risk pools, or "tranches," and then using a rating agency to rate the various pieces. In theory, at least, a AAA (or other) rating is supposed to represent the same degree of credit risk regardless of the particular instrument involved. For example, the credit risk on AAA-rated corporate debt and AAA-pieces of subprime securities should in theory be roughly the same. Since investors could presumably rely on rating agencies to take the place of their own due diligence, such ratings played a critical role in fostering the liquidity of private label MBS and, in this sense, achieved the same objective as the implicit guarantees of the GSEs.

However, several other important aspects of the GSE approach contributed to market liquidity in addition to their guarantee. The first is simply their size and market dominance. In general, the larger the volume of securities outstanding, the easier it is to match buyers with potential sellers, thereby enhancing market liquidity. One of the reasons that GSE MBS have traded so well over time is the growing volume of securities outstanding, which totaled about $\$ 4.4$ trillion at the end of 2008, or about 44 percent of all US Treasuries.

Another important contributor to the liquidity of the mortgage market is the "To Be Announced" or TBA market. The TBA market enables mortgage-backed securities to be bought or sold on a forward basis (i.e., prior to the time that the securities are actually formed.) While the mortgages that are ultimately used to support the security must have similar characteristics (defined by type, term and rate), the specific pool (or pools) of loans that will be used to support the securities do not have to be identified at the time of the actual trade. The forward selling of securities in the secondary market enables loan originators to commit to the terms and conditions of loans in advance of their actual funding. As a result, borrowers are able to lock-in their mortgage rates well before the mortgage is closed. At the same time, the homogeneity of the underlying pools gives investors the information and confidence they need to invest.

Largely as a result of their assumed or actual guarantees, GSE and Ginnie Mae pass-through securities are traded on a TBA basis, marking them the most liquid segment of the mortgage market. In contrast, a TBA market for private label securities has never been developed, in large part due to the complex nature of these instruments, their lack of government backing, and SEC 
registration requirements. While lock-ins are also available on nonconforming loans, the TBA market is typically used to hedge the interest rate risk. If the TBA market were to disappear, the costs of mortgages would undoubtedly rise, since lenders would have to turn to less suitable instruments to provide the hedge.

\subsection{Stability}

In addition to liquidity, the GSEs were created to ensure a stable and reliable flow of mortgage funding. While closely linked, liquidity and stability are not synonymous. Although privatelabel securities were able to provide a relatively high degree of liquidity in recent years, this liquidity rapidly disappeared when the market turned. Indeed, history has consistently shown that in times of crisis, the only way to ensure the continued flow of mortgage funding is to provide some form of government support.

The relative importance of an implicit or explicit government guarantee has never been more evident than it is today. As noted earlier, the GSEs and FHA now account for virtually all lending activity today. While the current crisis began in the subprime and Alt-A markets, it rapidly spread to jumbo mortgages. Despite their relatively strong performance, jumbo originations dropped by about 61 percent between the first quarter of 2007 and the first quarter of 2008. Issuances of securities backed by jumbo mortgages also fell precipitously, from about $\$ 120.9$ billion in 1 Q2007 to just $\$ 5.9$ billion in 1Q2008. Although some banks continue to originate jumbo loans and hold them in portfolios, their ability to do so has been severely limited by mounting credit losses and increasing demands on their capital.

In response to this situation, loan limits were raised to as high as $\$ 729,000$ in high cost markets as part of the January 2008 Economic Recovery Act. While the increase was originally scheduled to expire at the end of the year, it was subsequently extended through the end of 2009 with the passage of HERA. Originations of "newly conforming" jumbo loans were at first relatively low. However, once the high cost adjustments were extended ${ }^{19}$, the volume began to rise.

Although not as extreme, the patterns observed in the current market have been seen before. Spreads between the rates on jumbo and conventional conforming loans have typically ranged from about 25 to 50 basis points (bps). However, they have consistently widened in times of financial crisis, for example, immediately following the collapse of the Russian Bond Market in 1999 and 911 . Spreads today (about 140 bps) are now about three times as high as their historic

\footnotetext{
${ }^{19}$ Both the GSEs and lenders were initially reluctant to make the system adjustments required to implement the change. In addition, the Securities Industry and Financial Markets Association (SIFMA) opposed including such loans in TBA-eligible pools. (See SIFMA, "Including Jumbos in TBA-Eligible Pools Will Result in Higher Costs for Borrowers,” May 2008.) However, SIFMA has since reversed its earlier guidance.
} 
peak, reflecting the extreme lack of liquidity that continues to characterize the jumbo market. On the other hand, while rates on "newly conforming" jumbo mortgages were initially above those on "traditional" conforming mortgages, the difference has narrowed considerably, suggesting that high cost adjustments to the conforming loan limit have had their intended effect.

\subsection{Access to Affordable Housing Finance}

Finally, the GSEs were also charged with improving the distribution of mortgages and promoting access to affordable mortgage finance. For purposes of this discussion, we have divided this mandate into three components:

- Reducing geographic differences in the availability of mortgage funding ;

- Making mortgages more affordable to a broader segment of the population, for example, by lowering mortgage rates and reducing down payment requirements; and

- Serving specific segments of the population considered to be "underserved."

While the GSEs were generally successful in meeting the first two objectives, their track record on their specific affordable housing goals was mixed.

\subsubsection{Reducing Geographic Differences in the Availability of Mortgage Funding}

Prior to the development of the secondary market—and the lifting of interstate banking restrictions--local banks and S\&Ls were the primary source of mortgage lending. Since they relied on local deposits to fund the majority of their loans, rapidly growing markets-for example, parts of the South and the West—often found it difficult to meet local credit demands. This led to periodic credit rationing and/or spikes in mortgage rates. The opposite pattern occurred in declining markets where there was typically an excess supply of funds.

A Freddie Mac report documented the positive impact of the GSEs on the distribution of mortgage finance by examining regional trends in mortgage rates. ${ }^{20}$ During the 1960s and early 1970s, the difference between the highest and lowest regional mortgage rates was generally above one percentage point, rising sharply during periods of disintermediation in 1969-70 and 1973-74. By the late 1980s, the regional spread had narrowed to about 0.1 percentage points, a development that was largely attributed to the growth and development of the secondary market.

One could argue that the advent of interstate banking would make this benefit less important today. However, a recent study by Ambrose and Buttimer ${ }^{21}$ found that the GSEs continue to

\footnotetext{
${ }^{20}$ Freddie Mac, “Financing America’s Housing: The Vital Role of Freddie Mac”, Chapter 4, Exhibit 4.

${ }^{21}$ Ambrose, Brent W. \& Buttimer, Richard Jr., 2005. "GSE impact on rural mortgage markets," Regional Science and Urban Economics, Elsevier, vol. 35(4), pages 417-443, July.
} 
play an important role in reducing regional disparities in mortgage lending. In particular, the study found that prime jumbo lenders tended to avoid rural areas because the small number of transactions in such areas makes it difficult to value collateral. Fannie and Freddie, on the other hand, do as much (relative) business in these areas as anywhere else, because they are required to do so under their charters. The "information" risk arising from rural loans is therefore spread across all conforming lending.

More generally, one of the key benefits of the GSE approach is that it enabled a broad array of institutions to have access to capital markets, ranging from small community banks and mortgage brokers to the nation's largest depositories. This access undoubtedly helps to facilitate a more even and equitable distribution of housing finance than would otherwise be the case. Despite the consolidation that has occurred in the banking sector, geographic coverage remains uneven, particularly in older urban neighborhoods and rural communities. Providing a securitization outlet for smaller, less highly capitalized institutions helps to channel the flow of capital into areas that might not be otherwise served.

\subsection{Lowering Mortgage Rates}

Most empirical studies have also concluded that the GSEs have generally lowered mortgage rates by between 25 and 50 basis points (bps). While the GSEs have argued that at least some of these savings come from the efficiency and scale of their operations, most economists attribute the difference to their implicit guarantee. As we discussed in the previous section, the value of this guarantee varies with market conditions, along with the interest rate spread between conforming and jumbo loans. In general, mortgage spreads are relatively high in times of crisis — as they are today--and relatively low when the market has a relatively high tolerance for risk-as it did from 2005 through 2007. The same is true for cost of the GSEs' debt.

While most acknowledge that the GSEs have lowered mortgage rates, critics have argued that the GSEs and their shareholders have retained most of the benefits derived from their federal charters. In 1996, a CBO report estimated that less than 60 percent of the GSEs' funding benefits were passed through to consumers in the form of lower mortgage rates, a finding that led it to characterize the GSEs as "leaky" conduits. ${ }^{22}$ While the GSEs commissioned a number of reports to refute this charge, the evidence remains mixed. Indeed, the extent to which the benefits provided by the GSEs' federal charters are effectively “competed away” undoubtedly varies with the economic environment.

\subsubsection{Promoting Access to low down payment, fixed rate mortgages}

The GSEs also actively promoted a market for first time homeowners by making 30 year fixed rate mortgages available to borrowers who had relatively little to put down on their loans. By

\footnotetext{
${ }^{22}$ Assessing the Public Costs and Benefits of Fannie Mae and Freddie Mac, Congressional Budget Office, May 1996
} 
statute, Fannie Mae and Freddie Mac are required to obtain credit enhancement on loans with an LTV of greater than 80 percent. These credit enhancements include mortgage insurance (the most common form), participation, or recourse to the lender. Over the years, both agencies purchased large numbers of loans that fell into this category, thereby providing a cost effective and more efficient alternative to funding previously only available through FHA.

Recently, around 20 percent of Fannie Mae and Freddie Mac's mortgages have been "credit enhanced," meaning that they carry a credit enhancement. Among the mechanisms the institutions used to extend credit to those with small downpayments was the development of increasingly precise underwriting models. These models, along with subsequent review from mortgage insurance companies, had two effects: (1) they made more people eligible for low downpayment mortgages; (2) they effectively raised the LTV eligible for prime mortgage funding from 95 percent to 97 percent. Interestingly, Freddie Mac's book of low downpayment loans has performed significantly better FHA loans: the serious delinquency rate on FHA loans is about twice the rate on credit-enhanced Freddie Mac loans. ${ }^{23}$ However, credit enhanced Fannie Mae loans are performing relatively poorly. ${ }^{24}$

\subsubsection{Targeted Assistance to Underserved Groups}

In addition to lowering mortgage rates for the market at large, the GSEs were given specific Affordable Housing Goals in order to channel a significant portion of their purchase and investment activities to "underserved" borrowers and neighborhoods. These goals were raised significantly over the years by both Democratic and Republican administrations. For example, FHEFSSA established an initial goal of 30 percent for mortgages supporting low and moderate income owners and renters. This goal was increased to 40 percent in 1996, 42 percent in 2000, 50 percent in 2001, 52 percent in 2005, 53 percent in 2006, and 55 percent in $2007 .^{25}$ In fact, some conservative critics have claimed that the aggressive goals established for the GSEs ultimately led to the subprime crisis and the subsequent collapse of the financial sector. ${ }^{26}$

While there is little, if any empirical evidence to support this contention, perhaps a more telling question is whether the GSEs had much of an impact at all on the distribution of mortgage credit flowing to underserved groups. While the GSEs typically met most of their housing goals, most studies have found little, if any evidence that their activities have been particularly effective

\footnotetext{
${ }^{23}$ See Mortgage Bankers Association of America (http://www.mbaa.org/NewsandMedia/PressCenter/70050.htm) and Freddie Mac Monthly Volume Summary (2009), http://www.freddiemac.com/investors/volsum/, August

${ }^{24}$ See Fannie Mae Monthly Volume Summary (2009), http://www.fanniemae.com/ir/pdf/monthly/2009/083109.pdf;jsessionid=SOKOIDER5TZABJ2FQSISFGI

${ }^{25}$ http://www.huduser.org/Datasets/GSE/gse2007.pdf.

26 “The Role of Government Affordable Housing Policy in Creating the Global Financial Crisis of 2008.” Staff report, U.S. House of Representatives, Committee on Oversight and Government Reform, July7, 2009.
} 
compared to those of portfolio lenders. From the beginning, studies by the Federal Reserve and HUD have concluded that with only a few exceptions, both Fannie Mae and Freddie Mac were consistently "behind the market" in their purchase of so-called "affordable" loans (i.e., loans to lower income or minority borrowers or underserved neighborhoods.) In fact, this persistent finding helped to justify the aggressive increases in the GSEs’ Affordable Housing Goals.

Several studies by Stuart Gabriel and Stuart Rosen have also found little, if any impact of the GSEs on the supply of capital to lower income borrowers and communities. ${ }^{27}$ In particular, they "find no evidence of a positive impact of GSE underserved tract status on lending activity in the conforming sector or on local homeownership rates. In addition, underserved status has a negative impact on lending in the non-conforming sector. The absence of a positive GSE impact on conforming mortgage lending activity and homeownership in underserved tracts is striking given extensive loan purchase goals that mandate GSE purchases in such tracts.”

Thus, despite claims to the contrary, the body of evidence appears to suggest that the Affordable Housing Goals were not particularly effective in channeling funds to underserved areas. In part, this may reflect the fact that the GSEs were neither required nor inclined to subsidize loans to targeted neighborhoods or borrowers. It may also reflect a genuine disagreement on the underlying purpose of the GSEs. While some maintain that the GSEs should lead the market in terms of their service to targeted groups, others believe that their purpose is to ensure a secondary market outlet for such loans (i.e., to "match" the market.) In any event, the wholesale nature of the GSEs' activities has undoubtedly made it difficult for them to support the kind of highly specialized, tailored lending that typically characterizes community loans.

In the end, we believe that the GSEs made credit more accessible and available to the broader mortgage market. They also helped undermine the worst aspects of "relationship lending:" blatant preferences for white and male borrowers. One policy purpose of the GSEs--to make mortgages available everywhere--should surely remain in tact.

\subsection{Inherent Weaknesses and/or Criticisms of the GSE Approach}

While the GSE approach was highly successful in creating a liquid and stable mortgage market, critics have argued that these were accompanied by a number of inherent weaknesses that ultimately exposed the Federal government to an unnecessary level of risk. Some of these issues have already been described. Others are summarized below.

\footnotetext{
27 Gabriel, Stuart A. and Stuart Rosenthal. 2008a. "The GSEs, CRA and Homeownership in Targeted Underserved Neighborhoods." http://faculty.maxwell.syr.edu/rosenthal/. And 2008b. "Do the GSEs Expand the Supply of Mortgage Credit? New Evidence of Crowd Out in the Secondary Mortgage Market." http://faculty.maxwell.syr.edu/rosenthal/.
} 


\subsection{Moral Hazard and Insufficient Oversight}

Perhaps the most persistent criticism of the GSE model is associated with the moral hazard that arises from the government's implicit guarantee of their securities and debt. Since the guarantee is provided free of charge, critics have long maintained that Fannie Mae and Freddie Mac are incented to take on excessive risk in order to maximize shareholder profits and executive compensation, with federal taxpayers left holding the bag. This "privatization of profits and socialization of risk” has become a rallying cry for many GSE detractors.

FHEFSSA established a dedicated federal regulator for the GSEs--the Office of Federal Housing Enterprise Oversight (OFHEO)--to monitor the GSEs' safety and soundness. However, OFHEO's powers were relatively limited, and attempts to increase them over time were consistently overcome by aggressive lobbying on the part of the GSEs. Until the passage of the 2008 Housing and Economic Recovery Act, for example, OFHEO did not have the power to adjust the GSEs' capital requirements, limit their portfolio holdings, or otherwise take them into conservatorship or receivership in the event of impending failure.

Absent strong regulation, GSEs' incentives to manage their overall risk had to come from the market, company shareholders, or the GSEs themselves. Unfortunately, such self-regulation did not produce the desired results. Market discipline was lax as a result of the GSEs' government ties, and management at both GSEs ultimately succumbed to pressures to maintain their market shares in search of profitability. However, while it is tempting to attribute these short-comings to the inherent tensions between the public and private purposes of the GSEs, the same dynamics ultimately led to the demise of "purely private" financial entities. In our view, the events of the past two years demonstrate the importance of strong regulation and capital requirements in addition to an inherent weakness in the GSE model per se.

\subsection{Systemic Risk/Too Big to Fail}

Another related concern was that the GSEs had simply become too big to fail-a concern that ultimately proved to be justified. As noted earlier, GSE debt and securities are now an integral part of global capital markets. Since GSE mortgage-backed securities are given favorable capital treatment ${ }^{28}$, they are a significant part of banks' portfolio holdings. As a result, any significant deterioration in their market value would trigger a wave a secondary effects that would ultimately threaten the banking system. GSE debt is also widely distributed, with much of it held by foreign countries, particularly China. As a result, any devaluation of this debt would have international repercussions that transcended the US housing market. While the charge of "too big to fail" is hardly unique to the GSEs, it is a legitimate concern. The challenge is how to get the volume that is required for liquidity with less concentration and lower risk.

\footnotetext{
${ }^{28}$ Their risk-based weighted is only 20 percent, meaning that well capitalized banks need only hold 1.6 percent capital against MBS.
} 


\subsection{Lack of Competition}

Critics have also charged that the lack of competition between the two GSEs (and between the GSEs and the private sector) has led to excess profits and reduced the benefits that would have otherwise been received by consumers. While economic theory suggests that duopolies can be highly competitive, there are strong disagreements on whether this applies to Freddie Mac and Fannie Mae. In our view, the guarantee side of the GSEs' business was in fact highly competitive, as evidences by the steady erosion of their guarantee fees through much of the period. Average guarantee fees for Fannie Mae fell from around 25 basis points in the early 1980s to less than 20 bps in 2001; for Freddie Mac, they fell from a high of 26 bps in 1983 to 16.6 bps in $2005 .^{29}$

Nevertheless, the "appropriate” number of GSEs will be an issue going forward. Unless returns are regulated, two GSEs are clearly better than one. However, whether or not one should stop at only two is an open question. While additional GSEs would undoubtedly enhance competition, it is important to recognize the trade-off between concerns over excess profits and market liquidity. In general, as long as the securities are issued under the individual GSEs' names, increasing the number of GSEs will reduce the liquidity of their securities and ultimately, increase the cost of mortgages to consumers, thereby offsetting at least some of the potential gains.

\subsection{Concentration of Risk}

Another criticism of the GSE model is that it led to an unnecessary concentration of risk. Ironically, this argument typically focused on the GSES' growing portfolios and their increased exposure to interest rate risk. Because of their government ties, the GSEs were able to fund their mortgage holdings by issuing massage amounts of debt at favorable rates, and generate returns of 15 percent or more from the resulting spreads. While the authority to hold a certain amount of mortgages in portfolio can be justified on both operational and policy grounds-for example, it can help to stabilize markets in uncertain times - in our view, the large portfolios developed by the GSEs were primarily driven by the desire to maximize shareholder profits by taking advantage of their lower funding costs, and not their public mission.

At the same time, while it was widely recognized that the GSEs played an important role in the diversification of credit risk by pooling loans across geographic regions, relatively little attention was paid to the fact that as the GSEs increased their market share, credit risk became increasingly concentrated in their hands. To a large extent, this risk was offset by requirements that loans with down payments of less than 20 percent - the riskiest segment of the GSEs' business--carry private mortgage insurance, or PMI. Such insurance not only protected the

\footnotetext{
${ }^{29}$ See FHFA Annual Report to Congress, 2008, pages 1 and 127. http://www.fhfa.gov/webfiles/2335/FHFA_ReportToCongress2008508.pdf
} 
GSEs from a portion of their losses. It also subjected the loans to another set of eyes in assessing credit risk. Yet, as noted earlier, it was credit, not interest rate risk that ultimately brought the GSEs down.

\subsection{Inadequate Capital Standards}

With the advantages of hindsight, it is also clear that the GSEs' capital standards were insufficient to protect them from the meltdown of the housing market that began in late 2006. Under the guidelines, the GSEs were required to meet a capital ratio of 2.5 percent, or a "riskbased capital” requirement, whichever was higher. In theory, the risk-based capital standards were designed to enable the GSEs to survive two different 10-year scenarios of extreme market stress: one defined by the credit losses that occurred in the so-called "Oil Patch" states in the early 1980s; the other defined by a rising interest rate environment.

Risk-based capital standards were not implemented until 2002. However, in each year thereafter, the minimum capital requirement remained the binding constraint, i.e., the amount of capital required under the minimum capital standard was greater than the risk-based capital requirement. While this was true for both GSEs, the differences were particularly large for Freddie Mac. In 2007, for example, Freddie Mac’s risk-based capital requirement (\$14.1 billion) was only 53 percent of its minimum capital standard $(\$ 26,473 .)^{30}$ Yet within a year, Freddie Mac had a regulatory capital deficit of $\$ 41.3$ billion.

Despite the best intentions - and sophisticated analyses that were used to develop the standards and determine capital adequacy - the GSEs' capital requirements ultimately proved to be inadequate. Many papers will undoubtedly be written on what exactly went wrong. However, some potential candidates include:

- Failure to adequately account for the monoline nature of the GSEs' business and their resulting exposure to catastrophic risk;

- Mark-to-market accounting requirements in an environment when the market has ceased to function;

- The ability to use the value of future tax credits as a form of capital;

- The inability to predict the performance of new mortgage products such as Alt-A loans; and

- The ability to substitute the capital required for the investment and guarantee sides of their businesses, which tended to be offsetting.

\footnotetext{
${ }^{30}$ These figures exclude the 30 percent surcharge imposed on Freddie Mac at the end of 2003. Fannie Mae was also subject to a capital surcharge, beginning in 2005. See 2008 Annual Report, Federal Housing Finance Agency.

Tables 9 and 18.
} 
Once the current crisis passes, regulators will clearly have to go back to the drawing board and determine why seemingly state-of-the-art risked-based capital standards ultimately failed so miserably.

\subsection{Political Influence}

Finally, no discussion of the GSEs could be complete without at least a brief reference to their enormous political influence on Capitol Hill. Until their government takeovers, Fannie Mae and Freddie Mac were among the nation's largest political contributors, and their largess was directed to Democrats and Republicans alike. Both routinely held events in key Congressional districts announcing special affordable lending initiatives or grants to local nonprofits. Both routinely funded national nonprofits and advocacy groups that were useful to their cause. Both routinely hired executives with strong political ties.

Such activities served to protect the GSEs from repeated efforts to reign in their activities by unsympathetic members of Congress and by both the Clinton and Bush Administrations. In the end, it took their financial collapse-and an explicit prohibition to end all lobbying activities--to bring the GSEs' influence to a close. While aggressive lobbying activities are hardly unique to the GSEs, going forward, the regulator must be protected from the kind of political influence that made it difficult, if not impossible to implement meaningful reform.

\subsection{Principles for Reform}

The recent history of the GSEs and the broader mortgage market suggest several guiding principles that might be used in devising an alternative approach. While others could be added to the list, the principles discussed below provide a starting point for assessing the numerous proposals that have posited by advocates of GSE reform. The challenge is to redesign a system that retains most of the benefits that the GSEs have produced to date, while minimizing their major shortcomings.

\section{\# 1. Strong Regulation in both the Primary and Secondary Market}

Given the experience of the past two years, any proposal for GSE reform must include provisions for strong government oversight. While HERA replaced OFHEO with a new federal regulatorthe Federal Housing Finance Agency (FHFA) — and gave it significantly broader authorities and enforcement powers, it did so after most of the major damage had been done. Going forward, FHFA (or its successor) must continue to have the power and independence it needs to provide meaningful oversight. Efforts to strengthen the regulation of the secondary market need to be accompanied with increased oversight of the primary market and stronger consumer protections.

\section{\# 2. Appropriate Capital Standards}

Capital standards need to be sufficiently strong to ensure the long-term safety and soundness of the GSEs or their replacement entities. History has clearly shown that sophisticated models can 
be wrong; in the end, it is simply impossible to predict the future precisely from the past. As a result, the regulator must be given the power and the flexibility that it needs to adjust requirements on an as-needed basis. Issues concerning capital adequacy extend far beyond the GSEs, and will ultimately affect the future structure of the mortgage industry. Such standards should be consistent, meaningful, and designed to reflect the underlying risks that are assumed by any party or associated with any product.

\section{\# 3. Explicit Guarantee}

The experience of the past two years has also demonstrated the importance of a government guarantee in ensuring an adequate flow of mortgage funding in good times and bad. It is time to make the guarantee explicit. Even if one wanted to return to an "implicit" guarantee, the market would not believe it. It is better to provide an explicit guarantee--and be able to charge for itthan to continue with an approach that is the functional equivalent of "Don't ask, don't tell." Any guarantee should be structured in a way that minimizes moral hazard.

\section{\# 4. Market-driven Approach}

Any efforts for reform should also preserve the market-driven approach that was one of the major strengths of the GSEs. It is difficult to imagine how a government-owned entitywhether independent or part of another agency-could have produced the many socially valuable innovations that were spearheaded by the GSEs, such as state of the art underwriting tools. At the same time, a market-driven approach requires meaningful competition. The current system attempted to achieve this objective by creating two GSEs with identical charters. Any reform proposal needs to assess the extent to which it would encourage or impede a more competitive mortgage market.

\section{\# 5. $\quad$ Risk Sharing}

Proposals to reform the current system should also encourage risk sharing. Not only would this help to align incentives among the various parties involved in the transaction, it would also encourage the use of independent analytics and provide another set of eyes in assessing the credit risk.

It is important to recognize that the conventional conforming market already has the principle of risk-sharing embedded in its design. The GSEs are required to obtain private mortgage insurance (or other forms of credit enhancement) for any loan with an LTV above 80 percent. As a result, all high LTV loans have two entities involved in sharing the credit risk. ${ }^{31}$ In

\footnotetext{
${ }^{31}$ In addition, lenders who sell their loans into the secondary market are subject to repurchase requests in the event that the loans do not comply with established underwriting guidelines. Since lenders must hold reserves to cover any future repurchase requests, some consider this a form of risk-sharing, i.e., having "skin in the game.” However, since many originators were undercapitalized--and since the lenders were only responsible for adhering to
} 
contrast, investment banks and rating agencies effectively set the underwriting standards in the subprime market and had no skin in the game. As a result, they had little, if any incentive to manage the credit risk. While one could argue that the GSEs had insufficient skin in the game, their incentives were much closer to being appropriate than institutions who had no capital requirements and whose business was largely driven by fees.

\section{\# 6. Limited Portfolio Authority}

The GSEs' authority to hold loans in an investment portfolio should be priced properly and closely regulated. Although it was credit risk that ultimately brought the GSEs into conservatorship, this does not negate the continued interest rate risk that is associated with the \$1.6 trillion in mortgages they currently hold. While initially HERA required each GSE to reduce its mortgage assets by at least 10 percent each year until they reach of level of $\$ 250$ billion, this requirement has been suspended due to the continued turmoil in the market. Going forward, however, it is crucial that GSE portfolios be prevented from growing in response to $a$ subsidized interest rate bet. A tax on debt issuance such that the cost of capital for GSEs was similar to the cost of capital for institutions at similar risk would at once allow GSEs to have the portfolios necessary for dealing with times of crisis, while mitigating the problem of subsidizing risk taking. More robust capital standards would also reduce the attractiveness of debt-financed portfolios.

\section{\# 7. More Appropriate Affordable Housing Goals}

The Affordable Housing Goals also need to be reconsidered. Volume-oriented targets clearly did not work, and may have done more harm than good. At a minimum, the goals established for the GSEs should be consistent with the requirements imposed on the primary market to ensure a secondary outlet for such loans. To the extent that subsidies are desired, such subsidies should be made explicit. One approach would be to charge a fee for the government guarantee, and use part of the proceeds to subsidize mortgages to targeted groups, perhaps through a Housing Trust Fund. Another would be to require the GSEs to set aside a certain share of their pre-tax profits for activities and investments that directly support affordable housing. Presumably, making the subsidies more explicit would improve the allocation of scarce resource and lead to better public policy.

\section{\# 8. Renewed Focus on Multifamily Rental Housing}

Finally, while our discussions have clearly focused on the single-family side of the GSEs' businesses, any reform proposal must ensure the continued availability of mortgage funding for multifamily rental housing. This could be done by establishing a specialized conduit. Like other segments of the private market, the market for Commercial Mortgage-Backed Securities

established guidelines (as opposed to the guidelines themselves)--this form of risk-sharing was not particularly effective. 
(CMBS) has virtually disappeared, and is unlikely to come back any time soon. Although rental housing remains the only viable option for many of the country's lower income families, relatively little is currently being done to support investment in such properties.

\subsection{Alternative Models}

In this final section of the paper, we examine several alternative structures that have been proposed for the GSEs. While they by no means exhaust the range of proposals that have been or could be made, they represent the some of the major options identified thus far. In considering these different alternatives, we have made a number of key assumptions which are described below.

- The first is that the federal government should continue to promote a liquid and stable mortgage market. While some will undoubtedly argue that housing already absorbs too much of the nation's capital, we believe that continued support is justified on both social and economic grounds. As history has shown, a liquidity crisis in the mortgage market can quickly spread to other sectors of the economy, leading to widespread declines in consumption and employment. Since any financial reform is unlikely to eliminate future financial crises, the GSEs or their replacements must be built to withstand periodic shocks.

- We have also ruled out the possibility of a purely "private" solution. Absent a federal guarantee, a private sector approach cannot produce a consistent, reliable flow of mortgage lending. Although the federal government could conceivably provide a backstop in times of crisis-for example, the Federal Reserve could be authorized to purchase mortgages on an as-needed basis-this should be a measure of last resort.

- Likewise, we have assumed that transforming the GSEs into government agenciesperhaps by merging them in whole or in part with FHA and Ginnie Mae-would not produce the innovative, market-driven approach that has characterized the mortgage market for most of the past 30 years. While FHA will undoubtedly continue to play an important role for first-time homeowners, it should not be the source of liquidity for the overall market. However, in the event that a public option is selected, risk-sharing arrangements with the private sector should be encouraged, if not required. ${ }^{32}$

- Finally, we have limited our discussion to issues related specifically to Fannie Mae and Freddie Mac. Although we recognize that any solution will have to be achieved in the

\footnotetext{
${ }^{32}$ One such model, which was promoted by the MI industry at the beginning of the decade, would place private mortgage insurers in the first loss position, with FHA assuming the remainder of the risk. See Ann B. Schnare and Susan E. Woodward, “An Analysis of Ginnie Mae Choice,” July 2001.
} 
broader context of financial reform -including the future of FHA, Ginnie Mae and the Federal Home Loan Banks—such topics are simply beyond this paper’s scope.

With these caveats in mind, the following discussion looks at some of the major alternatives that are being considered by policy makers. These models include:

- a "status quo" approach, which would preserve most of Fannie Mae and Freddie Mac, but with stronger oversight, limited portfolio authorities, and an explicit guarantee.

- a "public utility" approach, which would limit the rate of return that could be earned by the GSEs;

- a "cooperative" approach, which would establish one or more GSEs that are owned by a consortium(s) of lenders;

- a "covered bond" approach, which would establish one or more GSEs to issue bonds collateralized by mortgages pledged by banks and carrying an FDIC-like guarantee;

- a "guaranteed MBS" approach, which would establish two or more federally chartered entities that would acquire and insure loans like the GSEs do today, but deliver them into a common security in a manner analogous to Ginnie Mae.

While other possibilities are clearly possible-and while the final solution is likely to be different from any of the specific models considered here--we believe that this exercise illustrates the broad advantages and disadvantages of different options for reform.

\subsection{Reconstituted GSEs}

Fannie Mae and Freddie Mac have long been strange hybrid creatures, and are accidents of history. Fannie was created as a public entity in 1938, and then split in two in 1968: the "new" Fannie Mae was to be a private company, while Ginnie Mae would be a public company that securitized government-insured mortgages. Fannie's hybrid nature arose at least in part because its debt was issued as public debt, and then became "private." This made the government's treatment of the company ambiguous. According to a former member of the Clinton Administration, there was a longstanding debate within the Treasury Department as to what to do in the event that Fannie (or Freddie) blew up-reinforcing the ambiguous nature of how much the government would in fact guarantee Fannie and Freddie debt.

As we have discussed, the GSEs actually worked quite well, and their contribution to systemic risk was quite negligible, until they began to increase rapidly the size of their portfolios in roughly 1997-1998. Before that point, their credit risk was manageable and, because their portfolios were fairly small, the interest rate risk they bore did not create systemic risk for the broader economy. In 1995, for example, the GSEs' total portfolios ( $\$ 350$ billion) was 5 percent of GDP (\$ 7.5 trillion.) Today, their portfolios (\$ 2 trillion) represent 15\% of GPD (\$14 trillion). 
At the same time, the GSE structure arguably allowed for the existence of 30 year fixed rate selfamortizing mortgages; households could offload their interest rate risk to entities such as insurance companies and pensions funds with long-duration liabilities. At the same time, because of their "implicit" government backing, the GSEs could raise capital during periods of stress in the financial markets. While other financial conduits shut down during the 1997-1998 financial crises and in the aftermath of the September 11, 2001 attacks, the residential mortgage market kept on cooking along with readily available capital and low spreads.

The clever characteristic of the GSE structure was the hybrid nature that is now under criticism. On the one hand, the fact that they were owned by shareholders, and had a valuable franchise, meant that they had incentives to cost minimize. On the other hand, when systemic risk outside of the housing market threatened to squeeze mortgage finance, the implied government backstop meant that they could continue to fund mortgages.

So far as we can tell, the only country other than the United States with long-duration, freely prepayable mortgages is Denmark. Denmark, like the United States, uses capital markets, rather than deposits, to fund mortgages, but the structure that it uses is a covered bond structure, and so differs from the GSE structure. Whether a covered bond structure would have performed so well during times of financial stress is an open question. Recent experience suggests that it would not.

But for the GSE structure to work going forward, a couple of geniis will need to be returned to their bottles. One genii, of course, never can be returned: "implicit" guarantees are gone for awhile, if not forever. For the GSE structure to work going forward, however, GSEs must return to being entities whose only mission is to fund prime mortgages. This means mortgages with substantial credit enhancements (either low LTVs or mortgage insurance); this means lending to borrowers with strong credit histories; this means purchasing only well documented loans.

We also now know that the GSEs used their funding advantage to build large portfolios that were, in the short run, highly profitable. They appeared profitable because of leverage: their capital bases were small, and so the difference between their cost of funds and their returns on mortgages was magnified by as much as 40 times. But this leverage also meant that their businesses were far more volatile than the underlying mortgage market-which has been quite volatile recently even on an unlevered basis. Many of us did not foresee just how volatile the mortgage market could be, but even so, many of us also worried about the rapid growth of the GSE portfolios.

Regulators could take three approaches to limiting the size of GSE portfolios. One-which is currently in place-would place a firm ceiling on portfolio size. While this would limit risk, it could also prevent the GSEs from providing liquidity at times of financial stress. The second approach would raise capital standards on mortgages. The GSEs have been required to hold 2.5 percent capital against their portfolios. If required capital was doubled, it would reduce volatility 
by 50 percent (this is a standard Modligiani-Miller result. ${ }^{33}$ ) It would also raise the cost of mortgage funding. If required return on equity is 15 percent above short-term Treasuries, and required return on equity was invariant to capital structure (a conservative assumption), then mortgage costs to borrowers would rise by 37 basis points. This might simply reflect appropriate pricing.

Alternatively, or in addition, Congress could require GSEs to pay taxes on newly issued debt, so that the cost of debt to GSEs would accurately reflect their risk. Finally, to make it clear that debt holders are on their own, the government could explicitly guarantee mortgage backed securities not held in Fannie and Freddie's portfolios, while explicitly not guaranteeing Fannie and Freddie debt. The combination of higher capital standards and a tax on debt would lead to a natural reduction in portfolio size.

It is worth noting that if the United States is going to continue to have fixed rate prepayable longterm mortgages, someone will have to hold interest rate risk. When depositories held it, as they did in the 1960s and 1970s, the government bailed them out. Were investment banks to hold it, precedent suggests that, in a crisis, the government would bail them out. Whomever holds the risk, the best policy can do is try to get the price and capital structure of it right. But it is difficult to believe that the GSE structure per se creates the risk.

\subsection{Single Conduit with a Regulated Rate of Return}

Federal Reserve Chair Ben Bernanke describes a utility-like model as another potential mechanism for mortgage funding ${ }^{34}$ :

A public utility model offers one possibility for incorporating private ownership. In such a model, the GSE remains a corporation with shareholders but is overseen by a public board. Beyond simply monitoring safety and soundness, the regulator would also establish pricing and other rules consistent with a promised rate of return to shareholders. Public utility regulation itself, of course, has numerous challenges and drawbacks, such as reduced incentives to control costs. Nor does this model completely eliminate the private-public conflict of the current GSE structure. But a public utility model might allow the enterprise to retain some of the flexibility and innovation associated with private-sector enterprises in which management is accountable to its shareholders. And, although I have noted the problems associated with private-public conflict, that conflict is not always counterproductive; an entity with private shareholders may be better able to resist political influences, which, under some circumstances, may lead to better market outcomes.

\footnotetext{
${ }^{33}$ Modigliani, F. and Miller, M. H. (1958). The Cost of Capital, Corporate Finance and the Theory of Investment. American Economic Review, 48, 261-97.

${ }^{34}$ http://www.federalreserve.gov/newsevents/speech/bernanke20081031a.htm, accessed on August 12, 2009.
} 
One could make a case that a conduit for mortgage funding is a natural monopoly since the fixed costs are high and the marginal costs are relatively constant. The fixed costs are the development of the infrastructure to underwrite mortgages and to pass cash flows through to investors in Mortgage Backed Securities in a timely and accurate manner. Such a setup involves heavy use of technology, and a staff of highly trained statistical and financial analysts. Fannie Mae and Freddie Mac both have hundreds of Ph.D.'s on their staffs, and their principal function is the development, calibration and review of underwriting and capital allocation models. This is expensive.

If the supply of capital for prime mortgage funding is elastic, the average cost curve for mortgage funding will be downward sloping at all relevant points. This means that the most efficient mortgage industry is one that has only one funding firm. But monopolies lead to suboptimal outcomes as well.

If this is an accurate depiction of the mortgage funding industry, it is very similar to a power utility, and therefore might be regulated in a similar manner. Some appealing features of the approach is that it employs private capital while closely regulating private returns and supports a more "highly focused" use of public benefits by restraining the types and size of mortgages that would be allowed. In addition, having a single mortgage conduit with regulated returns could help to level the playing field for small originators since guarantee fees would be set by the regulator, and not negotiated as they are today. As a result, adopting such an approach could help to counter the growing concentration in the primary mortgage market. A single mortgage conduit could also avoid the kind of destructive competitive behavior that some believe eventually led to a "race to the bottom” by Fannie Mae and Freddie Mac.

But there are challenges: how does government regulate mortgage pricing such that the mortgage conduit (1) engages in cost minimizing practices; (2) earns an acceptable, but not excessive return; and (3) responds appropriately to market needs?

In the context of the guarantee business, the cost of providing the guarantee consists of four components: the expected losses arising from default, overhead costs, float (although this is quite small) and a "reasonable" rate of return for investors. It would be up to the regulator to determine what constitutes "reasonable." This is problem enough. More problematic is the fact that default costs are tied to underwriting policy. Therefore, the regulator of the mortgage "utility" would have to be a partner in determining underwriting standards. This, again, is a problem.

At the end of the day, a regulated returns model would require reliance on highly standardized mortgages, and might be cumbersome and unresponsive to market conditions. This is one of the reasons so many utilities and utility-like industries, such as airlines, trucking companies, telecommunications companies, and power companies, became deregulated during the 1970s and 
1980s. The very pricing structure of utilities, moreover, reduces the incentive to reduce costs via innovation. The challenge would be to design a regulatory structure that minimizes such effects through an appropriate set of incentives.

\subsection{Cooperative Model'}

The United States has long had a cooperative model of mortgage finance alongside the more recent GSE Model. When Freddie Mac was created in 1970, it was a cooperative owned by savings and loans. One way the government helped the savings and loans recapitalize was by converting Freddie into a publicly traded company and allowing the thrifts to sell their cooperative interests. The Federal Home Loan Bank System is also essentially a cooperative, since the customers of the FHLBs--banks and savings and loans--are also its shareholders.

Spenser, Brown and Shields (2009) of the Federal Home Loan Bank of Atlanta argue that the Federal Home Loan Bank model has provided capital stability. They note:

The first benefit we attribute to the FHLBanks' cooperative structure is capital stability. This feature was cited by FHFA Director Lockhart at the time of Fannie Mae's and Freddie Mac's conservatorship and more recently after some of the FHLBanks suspended excess stock repurchases in order to build capital. Most of the FHLBanks' capital is contributed by members as a result of their use of FHLBank products, such as advances. Because advances are by far the largest asset class owned by the FHLBanks, this structure permits the FHLBanks' capital base to grow and shrink with their asset size and has sometimes been referred to as capital “on demand.”

They also argue that the FHLBs fulfill their mission better because they are not under pressure to earn a return on capital.

Flannery and Wall (2006) are not so sanguine about the safety of the FHLB coop structure. They note that the "joint and several liability" feature of the FHLBs creates serious moral hazard problems. And recent events have shown that the FHLBs have not been immune from getting into trouble. Recently, the San Francisco and Seattle FHLBs have faced capital shortfalls. And the Chicago FHLB has faced such large losses that it has considered merging with its Dallas counterpart. $^{35}$

The cooperative structure can also lead to self-dealing. Frame, Hancock and Passmore ${ }^{36}$ determined that the banks used FHLB advances for a variety of non-housing purposes. Because

\footnotetext{
${ }^{35}$ http://www.bizjournals.com/atlanta/stories/2008/11/24/story5.html

${ }^{36}$ W. Scott Frame \& Diana Hancock \& Wayne Passmore, 2007. "Federal Home Loan Bank advances and commercial bank portfolio composition," Finance and Economics Discussion Series 2007-31, Board of Governors of the Federal Reserve System (U.S.).
} 
money is fungible, banks could use FHLB advances to almost anything--including hiding capital short-falls.

Perhaps the greatest problem with the coop model is the issue of measuring capital. In the case of the FHLBs, it was very opaque: banks were required to purchase equity. Bank holdings were counted as tier-I capital. But the banks, of course, are highly levered. Finally, because the owners of cooperatives are also its customers, we see the possibility that a coop model would be dominated by large banks. One could argue that this has indeed happened in the Federal Home Loan Bank system.

\subsection{Covered Bonds}

Ribakova, Avesani and Pascual (2007) provide a good description of covered bonds as a funding mechanism for mortgages ${ }^{37}$ :

Covered bonds are debt instruments secured against a pool of mortgages to which the investor has a preferred claim in the event of an issuer default. In EU countries, the issuance of mortgage covered bonds is regulated by laws that define the criteria for eligible assets as well as various other specific requirements. In most cases, assets are earmarked as collateral for the outstanding covered bond and are kept in separate cover pools. In some countries (such as Spain), all mortgages on the balance sheet of the issuer are acting as collateral for the bonds. Following the 'cover principle', the outstanding amount and interest claims on covered bonds must be covered by the amount of eligible cover assets.

In contrast to other mortgage-backed securities (MBS), there is a special legal regime that governs the issuance and provides "special” protection to investors. The law governs the type of eligible assets for the covered pool, the asset/liability management (ALM), credit enhancements and over-collateralization requirements. Additionally, the cover pool remains on the balance sheet of the issuer and eligible assets are substitutable. Individual covered bonds do not face individual claims within the respective pool. Instead, all mortgage loans are facing the total volume of all outstanding mortgage bonds. In fact, mortgage cover pools are dynamic and of unlimited duration (when a loan meets the legal requirements, it is included in the existing pool). At the same time, when a loan is repaid or if, for other reasons, it no longer meets the quality criteria, it is withdrawn immediately. The large number of claims within the mortgage pools should offset the risks of individual claims, which constitutes an important safety criterion for the bondholder.

Covered bonds have worked well as a mechanism for funding loans in Germany, Spain and Denmark. But despite the features described above, only Denmark designs mortgages that have potentially long duration and have an effective mechanism for prepayment (borrowers in

\footnotetext{
${ }^{37}$ Elina Ribakova, Renzo Avesani and Antonio I Garcia Pascual (2007) See The Use of Mortgage Covered Bonds, IMF Working Paper No. 07/20.
} 
Denmark can purchase their mortgages back at par value at any time). While it is not entirely clear why this is the case, it does indicate a limitation with the instrument in a large market.

One point in the description, moreover, is particularly germane: "Additionally, the cover pool remains on the balance sheet of the issuer and eligible assets are substitutable." This creates a regulatory problem for banks. Unlike mortgage backed securities, which relieve banks of the need to hold capital against mortgage risk (because banks have offloaded the mortgages entirely), covered bonds would require banks to hold capital, which would perhaps make them less able to finance other types of business. If there were a move to a covered bond mechanism, it would be important to think through the implications of the instrument to mortgage borrowing (although perhaps consumers have paid too little for mortgages to this point on a risk adjusted basis, and requiring banks to hold them--even remotely--on their balance sheet would lead to more appropriate pricing.) Once again, we also have some concern that this model would ultimately be dominated by large banks, which would have economies of scale in bond issuance. The recent past suggests to us that maintaining a healthy community bank sector (i.e., a non-toobig-to-fail bank sector) is important.

\subsection{Multiple Conduits with Single Guaranteed Security}

A “Guaranteed MBS” approach would support a securitization model by providing an explicit federal guarantee on mortgage-backed securities issued by federally chartered mortgage conduits. $^{38}$ The government guarantee would ensure the liquidity and stability of the MBS market, and support the continuance of the 30 year fixed rate mortgage. It would also preserve the TBA market, which is critical to that liquidity. However, the federal guarantee would only apply to the MBS. It would not apply to the debt of the entity that issues the bonds.

Although there are many ways to structure a model of this kind, one approach would be to create a relatively small number (e.g., 3 to 5) of federally-chartered mortgage conduits that would acquire loans in the primary market and deliver them into a common security in a manner analogous to Ginnie Mae. The resulting securities would be guaranteed by an FDIC-like entity in exchange for an appropriate fee. Like a Ginnie Mae wrap, the federal guarantee would ensure the timely payment of principle and interest to MBS investors, and would only come into play in the event of a conduits' failure. The credit risk on the underlying mortgages would be held by the mortgage conduits and other market participants, including mortgage insurers.

Delivering loans into a common security would reduce barriers to entry and promote a level of liquidity that would be difficult to achieve if multiple entities issued multiple MBS. In addition, since the mortgage-backed securities would not be issued in the conduit's name, the systemic

\footnotetext{
${ }^{38}$ This general approach is discussed in O. Ravi and A. Mehta, "Future of the Housing Finance System and the GSEs,” The Mortgage Investor, Bank of America Merrill Lynch, August 7, 2009.
} 
risk associated with a conduit's failure would be much lower than is the case for Fannie Mae and Freddie Mac.

The debt or other obligations of the federally chartered conduits would not be subject to the federal guarantee. Since the federal guarantee would not apply to the conduits themselves, this will greatly reduce the moral hazard inherent in the current GSE approach. Moreover, due the use of a common issuer, the failure of one conduit will no longer threaten the collapse of the system as a whole. As a result, a conduit could be allowed to fail without jeopardizing the overall economy.

While the conduits could take many forms, competition among multiple conduits with identical missions would help to promote innovation and market efficiencies. This would not be the case if the GSEs were replaced with a single government agency such as FHA, or by an industryowned utility or cooperative. Since mortgages would be delivered to a common issuer for securitization, the model could accommodate more than two GSEs without jeopardizing the liquidity of the underlying securities. Indeed, one could begin by re-chartering Fannie Mae and Freddie Mac, and then add additional conduits over time.

One of the disadvantages of this approach is that it may be less appropriate for multifamily housing, which is less susceptible to securitization. The CMBS market has all but disappeared and is unlikely to come back anytime soon. Although the GSEs have issued a certain level of multifamily MBS over the years, they retained most of their multifamily purchases in their investment portfolios. Limiting the federal guarantee to securities issued by the mortgage conduit may have the unintended effect of disadvantaging rental housing. As a result, some consideration would have to be given on ways to mitigate such effects, including the creation of a conduit that focused exclusively on multifamily properties, exempting multifamily mortgages from any limitations that are imposed on the conduits' portfolios, or subsidizing the fee for the government wrap.

Another issue that would have to be resolved is the extent to which the conduits should be allowed to hold investment portfolios. At a minimum, limited portfolio authority would be required for operational and pooling purposes, and to ensure that small originators can continue to deliver mortgages on a loan-by-loan basis. In addition, limiting the GSEs' activities to the securitization side of the business could conceivably lead to higher mortgage rates. Since the GSEs will no longer have their investment portfolios as their major source of earnings, guarantee fees could rise even in the face of increased competition.

\subsection{Conclusions}

The models described above all have distinct advantages and disadvantages. Even if one accepts a given approach, there are numerous variants on each approach, each involving important policy issues. There are also thorny issues related to the restructuring (or dissolution) of Fannie Mae and Freddie Mac and how to handle their outstanding securities. Some have proposed 
splitting the Agencies into a "good bank" and a "bad bank," while others believe that the magnitude of their current losses would preclude a strategy of this kind. Regardless of what happens, parts of Fannie Mae and Freddie Mac are likely to survive, and provide at least some of the basic infrastructure for their replacements.

In the end, whatever approach is selected, it should be driven by the same policy objectives that led to the creation the GSEs, namely, to ensure a stable and liquid secondary mortgage market that meets the needs of investors and promotes access to affordable housing finance. While the solution might differ, these objectives are as relevant today as they were four decades ago, when Fannie Mae and Freddie Mac were first charged with creating a viable secondary market for conventional mortgages. 


\section{Exhibit 1}

\section{Combined GSE Market Share: 1990 -2008}

(\$ billions)

\begin{tabular}{|c|c|c|c|}
\hline Year & $\begin{array}{c}\text { Fannie/Freddie } \\
\text { New Business }\end{array}$ & $\begin{array}{c}\text { Total } \\
\text { Originations }\end{array}$ & Market Share \\
\hline 1990 & $\$ 190.33$ & $\$ 458.44$ & $41.5 \%$ \\
\hline 1991 & $\$ 242.90$ & $\$ 562.07$ & $43.2 \%$ \\
\hline 1992 & $\$ 452.26$ & $\$ 893.67$ & $50.6 \%$ \\
\hline 1993 & $\$ 524.77$ & $\$ 1,019.86$ & $51.5 \%$ \\
\hline 1994 & $\$ 288.27$ & $\$ 773.12$ & $37.3 \%$ \\
\hline 1995 & $\$ 230.99$ & $\$ 639.43$ & $36.1 \%$ \\
\hline 1996 & $\$ 300.36$ & $\$ 785.33$ & $38.2 \%$ \\
\hline 1997 & $\$ 290.26$ & $\$ 859.12$ & $33.8 \%$ \\
\hline 1998 & $\$ 657.39$ & $\$ 1,450.00$ & $45.3 \%$ \\
\hline 1999 & $\$ 640.82$ & $\$ 1,310.00$ & $48.9 \%$ \\
\hline 2000 & $\$ 467.27$ & $\$ 1,048.00$ & $44.6 \%$ \\
\hline 2001 & $\$ 1,089.88$ & $\$ 2,215.00$ & $49.2 \%$ \\
\hline 2002 & $\$ 1,491.30$ & $\$ 2,885.00$ & $51.7 \%$ \\
\hline 2003 & $\$ 2,249.48$ & $3,945.00$ & $57.0 \%$ \\
\hline 2004 & $\$ 1,219.97$ & $\$ 2,920.00$ & $41.8 \%$ \\
\hline 2005 & $\$ 1,164.06$ & $\$ 3,120.00$ & $37.3 \%$ \\
\hline 2006 & $\$ 1,115.84$ & $\$ 2,980.00$ & $37.4 \%$ \\
\hline 2007 & $\$ 1,323.81$ & $\$ 2,430.00$ & $54.5 \%$ \\
\hline 2008 & $\$ 1,078.11$ & $\$ 1,485.00$ & $72.6 \%$ \\
\hline
\end{tabular}

Sources: Inside Mortgage Finance Yearbook for 2007, p. 3; 2008 data from "Stabilizing the Mortgage Market" by James B. Lockhart III, speech given before the Urban Land Institute Terwilliger Center Annual Forum, slide 5 


\section{Exhibit 2}

\section{Outstanding Mortgage Securities: 1990 - 2008}

(\$ millions)

\begin{tabular}{|c|c|c|c|c|c|}
\hline \multirow[b]{2}{*}{ Year } & \multirow[b]{2}{*}{$\begin{array}{c}\text { Ginnie } \\
\text { Mae MBS }\end{array}$} & \multirow[b]{2}{*}{$\begin{array}{l}\text { Non- } \\
\text { agency } \\
\text { MBS }\end{array}$} & \multicolumn{3}{|c|}{ GSEs } \\
\hline & & & $\begin{array}{c}\text { Freddie } \\
\text { Mac 1-4 } \\
\text { PCs }\end{array}$ & $\begin{array}{c}\text { Fannie } \\
\text { Mae 1-4 } \\
\text { MBS }\end{array}$ & Total \\
\hline 1990 & $\$ 401,278$ & $\$ 55,000$ & $\$ 320,959$ & $\$ 289,683$ & $\$ 610,642$ \\
\hline 1991 & $\$ 425,241$ & $\$ 96,700$ & $\$ 364,163$ & $\$ 360,549$ & $\$ 724,712$ \\
\hline 1992 & $\$ 419,516$ & $\$ 142,300$ & $\$ 412,808$ & $\$ 433,353$ & $\$ 846,161$ \\
\hline 1993 & $\$ 414,066$ & $\$ 167,900$ & $\$ 453,276$ & $\$ 483,666$ & $\$ 936,942$ \\
\hline 1994 & $\$ 450,934$ & $\$ 183,000$ & $\$ 489,176$ & $\$ 517,116$ & 5,292 \\
\hline 1995 & $\$ 472$ & $\$ 193,800$ & $\$ 512,376$ & $\$ 565,567$ & 77,943 \\
\hline 1996 & $\$ 506,340$ & $\$ 215,400$ & $\$ 551,070$ & $\$ 628,757$ & $\$ 1,179,827$ \\
\hline 1997 & $\$ 536,810$ & $\$ 253,500$ & $\$ 575,665$ & $\$ 683,124$ & $\$ 1,258,789$ \\
\hline 1998 & $\$ 537,431$ & $\$ 321,500$ & $\$ 642,209$ & $\$ 799,983$ & $\$ 1,442,192$ \\
\hline 1999 & $\$ 582,263$ & $\$ 353,200$ & $\$ 744,339$ & $\$ 922,138$ & $\$ 1,666,477$ \\
\hline 2000 & $\$ 611,553$ & $\$ 377,500$ & $\$ 816,302$ & $\$ 1,014,301$ & $\$ 1,830,603$ \\
\hline 2001 & $\$ 591,368$ & $\$ 463,200$ & $\$ 954,054$ & $\$ 1,242,703$ & $\$ 2,196,757$ \\
\hline 2002 & $\$ 537,888$ & $\$ 544,100$ & $\$ 1,062,016$ & $\$ 1,365,779$ & $\$ 2,427,795$ \\
\hline 2003 & $\$ 473,738$ & $\$ 666,000$ & $\$ 1,129,150$ & $\$ 1,641,641$ & $\$ 2,770,791$ \\
\hline 2004 & $\$ 441,235$ & $\$ 1,045,700$ & $\$ 1,193,422$ & $\$ 1,694,408$ & $\$ 2,887,830$ \\
\hline 2005 & $\$ 405,246$ & $\$ 1,618,000$ & $\$ 1,321,021$ & $\$ 1,780,352$ & $\$ 3,101,373$ \\
\hline 2006 & $\$ 410,196$ & $\$ 2,128,300$ & $\$ 1,468,608$ & $\$ 1,932,927$ & $\$ 3,401,535$ \\
\hline 2007 & $\$ 449,705$ & $\$ 2,162,600$ & $\$ 1,727,275$ & $\$ 2,259,256$ & $\$ 3,986,531$ \\
\hline 2008 & $\$ 597,206$ & $\$ 1,838,600$ & $\$ 1,812,409$ & $\$ 2,545,059$ & $\$ 4,357,468$ \\
\hline
\end{tabular}

Source: The 2009 Mortgage Market Statistical Annual, Volume II, p. 10 


\section{Exhibit 3}

\section{Fannie Mae and Freddie Mac Total Mortgage Assets: 1990-2009}

(\$ millions)

\begin{tabular}{|c|c|c|c|}
\hline Year & Fannie Mae & Freddie Mac & Total \\
\hline 1990 & $\$ 114,066$ & $\$ 21,520$ & $\$ 135,586$ \\
\hline 1991 & $\$ 126,679$ & $\$ 26,667$ & $\$ 153,346$ \\
\hline 1992 & $\$ 156,260$ & $\$ 33,629$ & $\$ 189,889$ \\
\hline 1993 & $\$ 190,169$ & $\$ 55,938$ & $\$ 246,107$ \\
\hline 1994 & $\$ 220,815$ & $\$ 73,171$ & $\$ 293,986$ \\
\hline 1995 & $\$ 252,868$ & $\$ 107,706$ & $\$ 360,574$ \\
\hline 1996 & $\$ 286,528$ & $\$ 137,826$ & $\$ 424,354$ \\
\hline 1997 & $\$ 316,592$ & $\$ 164,543$ & $\$ 481,135$ \\
\hline 1998 & $\$ 415,434$ & $\$ 255,670$ & $\$ 671,104$ \\
\hline 1999 & $\$ 523,103$ & $\$ 322,914$ & $\$ 846,017$ \\
\hline 2000 & $\$ 607,731$ & $\$ 385,451$ & $\$ 993,182$ \\
\hline 2001 & $\$ 706,347$ & $\$ 503,769$ & $\$ 1,210,116$ \\
\hline 2002 & $\$ 820,627$ & $\$ 589,899$ & $\$ 1,410,526$ \\
\hline 2003 & $\$ 919,589$ & $\$ 660,531$ & $\$ 1,580,120$ \\
\hline 2004 & $\$ 925,194$ & $\$ 664,582$ & $\$ 1,589,776$ \\
\hline 2005 & $\$ 736,803$ & $\$ 709,503$ & $\$ 1,446,306$ \\
\hline 2006 & $\$ 726,434$ & $\$ 700,002$ & $\$ 1,426,436$ \\
\hline 2007 & $\$ 723,620$ & $\$ 710,042$ & $\$ 1,433,662$ \\
\hline 2008 & $\$ 767,989$ & $\$ 748,746$ & $\$ 1,516,735$ \\
\hline 2009 & $\$ 789,634$ & $\$ 823,431$ & $\$ 1,613,065$ \\
\hline
\end{tabular}

Sources: 2008 FHFA Annual Report to Congress, pp. 111 and 128; Fannie Mae and Freddie Mac Investor Relations 


\section{Exhibit 4}

\section{GSE Mortgage-Related Security Purchases: 1990-2008}

(\$ millions)

\begin{tabular}{|c|c|c|c|c|c|c|}
\hline & \multicolumn{3}{|c|}{ Fannie Mae } & \multicolumn{3}{c|}{ Freddie Mac } \\
\cline { 2 - 6 } & $\begin{array}{c}\text { Total } \\
\text { Private- } \\
\text { Yeabel }\end{array}$ & $\begin{array}{c}\text { Total Mortgage- } \\
\text { Related Securities }\end{array}$ & $\begin{array}{c}\text { Private-to- } \\
\text { Total } \\
\text { Ratio }\end{array}$ & $\begin{array}{c}\text { Total } \\
\text { Private- } \\
\text { Label }\end{array}$ & $\begin{array}{c}\text { Total Mortgage- } \\
\text { Related Securities }\end{array}$ & $\begin{array}{c}\text { Potal } \\
\text { Ratio }\end{array}$ \\
\hline 2008 & $\$ 2,295$ & $\$ 77,523$ & $3.0 \%$ & $\$ 10,316$ & $\$ 297,614$ & $3.5 \%$ \\
\hline 2007 & $\$ 37,435$ & $\$ 69,236$ & $54.1 \%$ & $\$ 76,134$ & $\$ 231,039$ & $33.0 \%$ \\
\hline 2006 & $\$ 57,787$ & $\$ 102,666$ & $56.3 \%$ & $\$ 122,230$ & $\$ 241,205$ & $50.7 \%$ \\
\hline 2005 & $\$ 41,369$ & $\$ 62,232$ & $66.5 \%$ & $\$ 179,962$ & $\$ 325,575$ & $55.3 \%$ \\
\hline 2004 & $\$ 90,747$ & $\$ 176,385$ & $51.4 \%$ & $\$ 121,082$ & $\$ 223,299$ & $54.2 \%$ \\
\hline 2003 & $\$ 34,032$ & $\$ 408,606$ & $8.3 \%$ & $\$ 69,154$ & $\$ 385,078$ & $18.0 \%$ \\
\hline 2002 & $\$ 7,416$ & $\$ 268,574$ & $2.8 \%$ & $\$ 59,376$ & $\$ 299,674$ & $19.8 \%$ \\
\hline 2001 & $\$ 3,513$ & $\$ 209,124$ & $1.7 \%$ & $\$ 24,468$ & $\$ 248,466$ & $9.8 \%$ \\
\hline 2000 & $\$ 8,466$ & $\$ 129,716$ & $6.5 \%$ & $\$ 10,304$ & $\$ 91,896$ & $11.2 \%$ \\
\hline 1999 & $\$ 16,511$ & $\$ 169,905$ & $9.7 \%$ & $\$ 15,263$ & $\$ 101,898$ & $15.0 \%$ \\
\hline 1998 & $\$ 15,721$ & $\$ 147,260$ & $10.7 \%$ & $\$ 15,711$ & $\$ 128,446$ & $12.2 \%$ \\
\hline 1997 & $\$ 4,188$ & $\$ 50,317$ & $8.3 \%$ & $\$ 1,494$ & $\$ 35,385$ & $4.2 \%$ \\
\hline 1996 & $\$ 777$ & $\$ 46,743$ & $1.7 \%$ & & & \\
\hline 1995 & $\$ 752$ & $\$ 36,258$ & $2.1 \%$ & & & \\
\hline 1994 & $\$ 0$ & $\$ 25,905$ & $0.0 \%$ & & & \\
\hline 1993 & $\$ 0$ & $\$ 6,606$ & $0.0 \%$ & & & \\
\hline 1992 & $\$ 0$ & $\$ 5,428$ & $0.0 \%$ & & & \\
\hline 1991 & $\$ 0$ & $\$ 3,080$ & $0.0 \%$ & & & \\
\hline 1990 & $\$ 0$ & $\$ 1,451$ & $0.0 \%$ & & & \\
\hline
\end{tabular}

Source: 2008 FHFA Annual Report to Congress, pp. 107 and 124 


\section{Exhibit 5}

\section{Fannie Mae and Freddie Mac Debt Outstanding and U.S. Treasuries Outstanding}

(\$ millions)

\begin{tabular}{|c|c|c|c|c|}
\hline & $\begin{array}{c}\text { Fannie } \\
\text { Debt } \\
\text { Year }\end{array}$ & $\begin{array}{c}\text { Freddie } \\
\text { Debt } \\
\text { Outstanding }\end{array}$ & $\begin{array}{c}\text { Total F/F } \\
\text { Debt } \\
\text { Outstanding }\end{array}$ & $\begin{array}{c}\text { Treasuries } \\
\text { Outstanding }\end{array}$ \\
\hline 1990 & $\$ 123,403$ & $\$ 30,941$ & $\$ 154,344$ & $\$ 3,233,313$ \\
\hline 1991 & $\$ 133,937$ & $\$ 30,262$ & $\$ 164,199$ & $\$ 3,665,303$ \\
\hline 1992 & $\$ 166,300$ & $\$ 29,631$ & $\$ 195,931$ & $\$ 4,064,621$ \\
\hline 1993 & $\$ 201,112$ & $\$ 49,993$ & $\$ 251,105$ & $\$ 4,411,489$ \\
\hline 1994 & $\$ 257,230$ & $\$ 93,279$ & $\$ 350,509$ & $\$ 4,692,750$ \\
\hline 1995 & $\$ 299,174$ & $\$ 119,961$ & $\$ 419,135$ & $\$ 4,973,983$ \\
\hline 1996 & $\$ 331,270$ & $\$ 156,981$ & $\$ 488,251$ & $\$ 5,224,811$ \\
\hline 1997 & $\$ 369,774$ & $\$ 172,842$ & $\$ 542,616$ & $\$ 5,413,146$ \\
\hline 1998 & $\$ 460,291$ & $\$ 287,396$ & $\$ 747,687$ & $\$ 5,526,193$ \\
\hline 1999 & $\$ 547,619$ & $\$ 360,711$ & $\$ 908,330$ & $\$ 5,656,271$ \\
\hline 2000 & $\$ 642,682$ & $\$ 426,899$ & $\$ 1,069,581$ & $\$ 5,674,178$ \\
\hline 2001 & $\$ 763,467$ & $\$ 578,368$ & $\$ 1,341,835$ & $\$ 5,807,463$ \\
\hline 2002 & $\$ 841,293$ & $\$ 665,696$ & $\$ 1,506,989$ & $\$ 6,228,236$ \\
\hline 2003 & $\$ 961,280$ & $\$ 739,613$ & $\$ 1,700,893$ & $\$ 6,783,231$ \\
\hline 2004 & $\$ 953,111$ & $\$ 731,697$ & $\$ 1,684,808$ & $\$ 7,379,053$ \\
\hline 2005 & $\$ 764,010$ & $\$ 748,792$ & $\$ 1,512,802$ & $\$ 7,932,710$ \\
\hline 2006 & $\$ 767,046$ & $\$ 744,341$ & $\$ 1,511,387$ & $\$ 8,506,974$ \\
\hline 2007 & $\$ 796,299$ & $\$ 738,557$ & $\$ 1,534,856$ & $\$ 9,007,653$ \\
\hline 2008 & $\$ 870,393$ & $\$ 843,021$ & $\$ 1,713,414$ & $\$ 10,024,725$ \\
\hline
\end{tabular}

Sources: 2008 FHFA Annual Report to Congress, pp. 111 and 128; TreasuryDirect Historical Debt Outstanding, available at http://www.treasurydirect.gov/govt/reports/pd/histdebt/histdebt_histo5.htm 


\section{Exhibit 6}

Fannie Mae and Freddie Mac Stock Prices (1990 = 1)

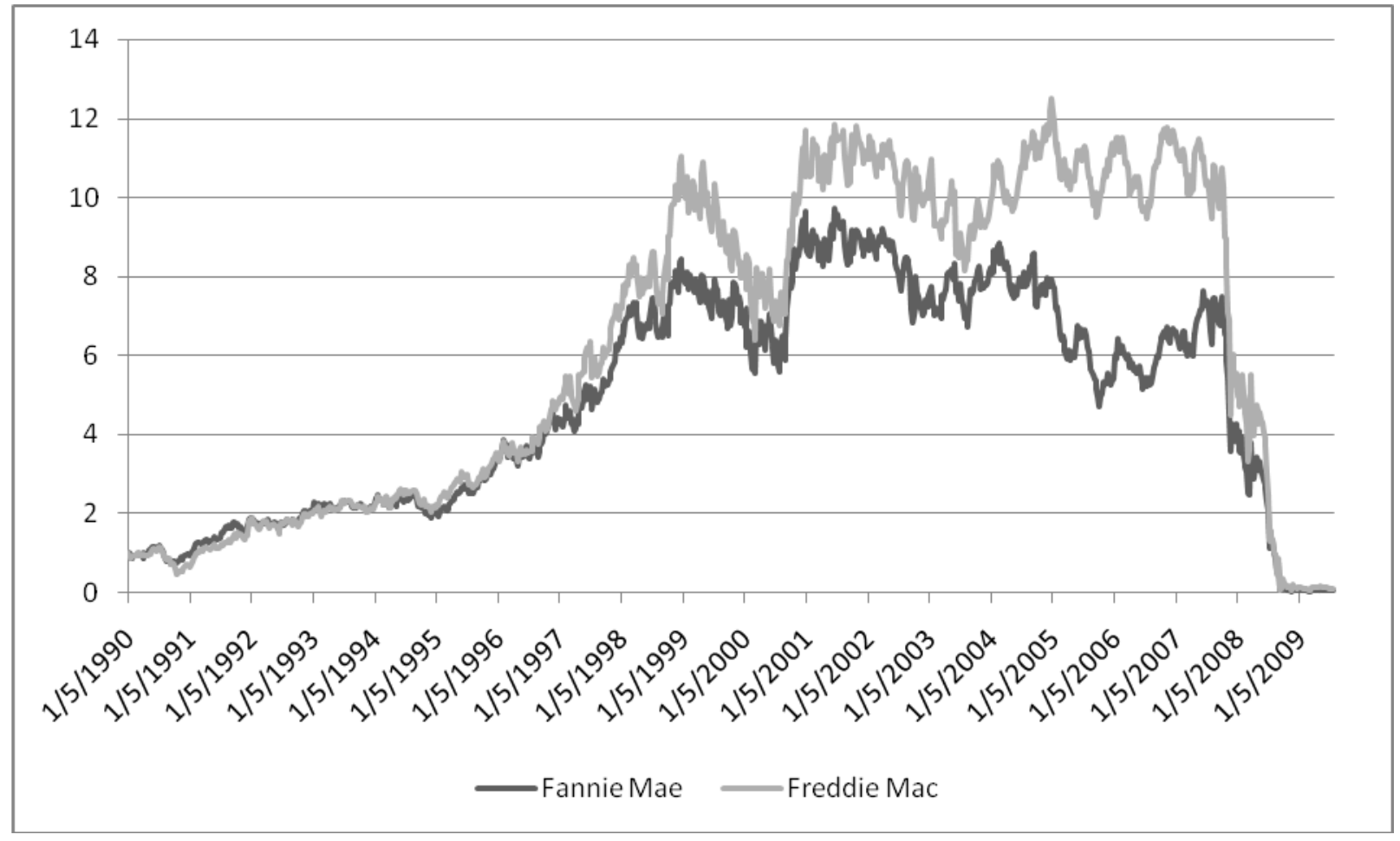

Source: Google Finance 


\section{Exhibit 7}

Mortgage Originations by Product Type: 1990 to 2008

(\$ billions)

\begin{tabular}{|c|c|c|c|c|c|c|}
\hline Year & FHA/VA & Conv/Conf & Jumbo & Subprime & Alt-A & Total \\
\hline 1990 & $\$ 70$ & $\$ 240$ & $\$ 88$ & $\$ 37$ & $\$ 3$ & $\$ 438$ \\
\hline 1991 & $\$ 62$ & $\$ 300$ & $\$ 113$ & $\$ 53$ & $\$ 6$ & $\$ 534$ \\
\hline 1992 & $\$ 73$ & $\$ 530$ & $\$ 160$ & $\$ 80$ & $\$ 9$ & $\$ 852$ \\
\hline 1993 & $\$ 119$ & $\$ 590$ & $\$ 175$ & $\$ 85$ & $\$ 11$ & $\$ 980$ \\
\hline 1994 & $\$ 141$ & $\$ 356$ & $\$ 150$ & $\$ 75$ & $\$ 10$ & $\$ 732$ \\
\hline 1995 & $\$ 75$ & $\$ 315$ & $\$ 135$ & $\$ 60$ & $\$ 10$ & $\$ 595$ \\
\hline 1996 & $\$ 105$ & $\$ 380$ & $\$ 160$ & $\$ 70$ & $\$ 20$ & $\$ 735$ \\
\hline 1997 & $\$ 100$ & $\$ 405$ & $\$ 190$ & $\$ 85$ & $\$ 25$ & $\$ 805$ \\
\hline 1998 & $\$ 145$ & $\$ 705$ & $\$ 355$ & $\$ 135$ & $\$ 35$ & $\$ 1,375$ \\
\hline 1999 & $\$ 172$ & $\$ 595$ & $\$ 315$ & $\$ 130$ & $\$ 40$ & $\$ 1,252$ \\
\hline 2000 & $\$ 115$ & $\$ 495$ & $\$ 260$ & $\$ 100$ & $\$ 25$ & $\$ 995$ \\
\hline 2001 & $\$ 175$ & $\$ 1,265$ & $\$ 460$ & $\$ 160$ & $\$ 40$ & $\$ 2,100$ \\
\hline 2002 & $\$ 176$ & $\$ 1,706$ & $\$ 571$ & $\$ 200$ & $\$ 67$ & $\$ 2,720$ \\
\hline 2003 & $\$ 220$ & $\$ 2,460$ & $\$ 650$ & $\$ 310$ & $\$ 85$ & $\$ 3,725$ \\
\hline 2004 & $\$ 135$ & $\$ 1,210$ & $\$ 515$ & $\$ 540$ & $\$ 190$ & $\$ 2,590$ \\
\hline 2005 & $\$ 90$ & $\$ 1,090$ & $\$ 570$ & $\$ 625$ & $\$ 380$ & $\$ 2,755$ \\
\hline 2006 & $\$ 80$ & $\$ 990$ & $\$ 480$ & $\$ 600$ & $\$ 400$ & $\$ 2,550$ \\
\hline 2007 & $\$ 116$ & $\$ 1,151$ & $\$ 348$ & $\$ 191$ & $\$ 275$ & $\$ 2,081$ \\
\hline 2008 & $\$ 290$ & $\$ 920$ & $\$ 97$ & $\$ 23$ & $\$ 41$ & $\$ 1,371$ \\
\hline
\end{tabular}

Source: The 2009 Mortgage Market Statistical Annual, Volume I, p. 4 


\section{Exhibit 8}

\section{MBS issuances by Type: 1995 to 2009}

\section{(\$ millions)}

\begin{tabular}{|c|c|c|c|c|c|c|c|c|c|}
\hline \multirow[b]{2}{*}{ Year } & \multirow[b]{2}{*}{ GNMA } & \multirow[b]{2}{*}{ FHLMC } & \multirow[b]{2}{*}{ FNMA } & \multicolumn{5}{|c|}{ Non-Agency } & \multirow[b]{2}{*}{ Total } \\
\hline & & & & Prime & Subprime & Alt-A & Other & $\begin{array}{l}\text { Total Non- } \\
\text { Agency }\end{array}$ & \\
\hline 1995 & $\$ 72,763$ & $\$ 85,877$ & $\$ 110,456$ & $\$ 25,838$ & $\$ 17,771$ & $\$ 498$ & $\$ 4,818$ & $\$ 48,926$ & $\$ 318,022$ \\
\hline 1996 & $\$ 100,880$ & $\$ 119,702$ & $\$ 149,849$ & $\$ 31,419$ & $\$ 30,769$ & $\$ 1,803$ & $\$ 55,903$ & $\$ 69,893$ & $\$ 440,324$ \\
\hline 1997 & $\$ 103,743$ & $\$ 114,528$ & $\$ 149,429$ & $\$ 49,975$ & $\$ 56,921$ & $\$ 6,518$ & $\$ 5,719$ & $\$ 119,132$ & $\$ 486,832$ \\
\hline 1998 & $\$ 149,112$ & $\$ 250,764$ & $\$ 326,148$ & $\$ 97,365$ & $\$ 75,830$ & $\$ 21,236$ & $\$ 8,780$ & $\$ 203,211$ & $\$ 929,234$ \\
\hline 1999 & $\$ 151,410$ & $\$ 233,031$ & $\$ 300,689$ & $\$ 74,631$ & $\$ 55,852$ & $\$ 12,023$ & $\$ 5,394$ & $\$ 147,899$ & $\$ 833,029$ \\
\hline 2000 & $\$ 103,251$ & $\$ 165,624$ & $\$ 210,205$ & $\$ 53,585$ & $\$ 52,467$ & $\$ 16,444$ & $\$ 13,463$ & $\$ 135,959$ & $\$ 615,039$ \\
\hline 2001 & $\$ 172,708$ & $\$ 389,611$ & $\$ 525,321$ & $\$ 142,203$ & $\$ 87,053$ & $\$ 11,374$ & $\$ 26,691$ & $\$ 267,320$ & $\$ 1,354,965$ \\
\hline 2002 & $\$ 172,135$ & $\$ 547,056$ & $\$ 723,299$ & $\$ 171,534$ & $\$ 122,681$ & $\$ 53,463$ & $\$ 66,277$ & $\$ 413,955$ & $\$ 1,856,893$ \\
\hline 2003 & $\$ 217,716$ & $\$ 713,787$ & $\$ 1,198,616$ & $\$ 237,455$ & $\$ 194,959$ & $\$ 74,151$ & $\$ 79,652$ & $\$ 586,216$ & $\$ 2,717,133$ \\
\hline 2004 & $\$ 124,388$ & $\$ 365,148$ & $\$ 527,145$ & $\$ 233,378$ & $\$ 362,549$ & $\$ 158,586$ & $\$ 109,639$ & $\$ 864,152$ & $\$ 1,882,836$ \\
\hline 2005 & $\$ 85,766$ & $\$ 397,867$ & $\$ 481,260$ & $\$ 280,704$ & $\$ 465,036$ & $\$ 332,323$ & $\$ 109,388$ & $\$ 1,191,263$ & $\$ 2,155,987$ \\
\hline 2006 & $\$ 82,275$ & $\$ 360,023$ & $\$ 456,857$ & $\$ 219,037$ & $\$ 448,600$ & $\$ 365,676$ & $\$ 112,139$ & $\$ 1,145,612$ & $\$ 2,045,420$ \\
\hline 2007 & $\$ 95,511$ & $\$ 444,312$ & $\$ 617,707$ & $\$ 180,462$ & $\$ 201,547$ & $\$ 249,610$ & $\$ 75,394$ & $\$ 707,013$ & $\$ 1,867,676$ \\
\hline 2008 & $\$ 269,046$ & $\$ 357,861$ & $\$ 541,960$ & $\$ 6,658$ & $\$ 2,261$ & $\$ 1,855$ & $\$ 47,358$ & $\$ 51,452$ & $\$ 1,168,867$ \\
\hline
\end{tabular}

Source: The 2009 Mortgage Market Statistical Annual, Volume II, pp. 9 and 13 


\section{Exhibit 9}

\section{Private-Label Securities of Fannie Mae and Freddie Mac}

\section{(\$ millions)}

\begin{tabular}{|c|c|c|c|c|c|c|c|c|c|}
\hline \multirow[b]{3}{*}{ Year } & \multicolumn{7}{|c|}{ Single Family } & \multirow[b]{3}{*}{$\begin{array}{l}\text { Multi- } \\
\text { family }\end{array}$} & \multirow{3}{*}{$\begin{array}{c}\text { Total } \\
\text { Private } \\
\text { Label }\end{array}$} \\
\hline & \multirow{2}{*}{$\begin{array}{l}\text { Manu- } \\
\text { factured } \\
\text { Housing }\end{array}$} & \multicolumn{2}{|c|}{ Subprime } & \multicolumn{2}{|c|}{ Alt-A } & \multicolumn{2}{|c|}{ Other } & & \\
\hline & & $\begin{array}{l}\text { Fixed } \\
\text { Rate }\end{array}$ & $\begin{array}{l}\text { Adjustable } \\
\text { Rate }\end{array}$ & $\begin{array}{l}\text { Fixed } \\
\text { Rate }\end{array}$ & $\begin{array}{c}\text { Adjustable } \\
\text { Rate }\end{array}$ & $\begin{array}{l}\text { Fixed } \\
\text { Rate }\end{array}$ & $\begin{array}{c}\text { Adjustable } \\
\text { Rate }\end{array}$ & & \\
\hline \multicolumn{10}{|c|}{ Freddie Mac } \\
\hline 2008 & $\$ 0$ & $\$ 8,199$ & $\$ 46$ & $\$ 0$ & $\$ 618$ & $\$ 36$ & $\$ 0$ & $\$ 1,416$ & $\$ 10,315$ \\
\hline 2007 & $\$ 127$ & $\$ 843$ & $\$ 42,824$ & $\$ 702$ & $\$ 9,306$ & $\$ 48$ & $\$ 0$ & $\$ 22,284$ & $\$ 76,134$ \\
\hline 2006 & $\$ 0$ & $\$ 116$ & $\$ 74,645$ & $\$ 718$ & $\$ 29,828$ & $\$ 48$ & $\$ 0$ & $\$ 16,875$ & $\$ 122,230$ \\
\hline \multicolumn{10}{|c|}{ Fannie Mae } \\
\hline 2008 & $\$ 0$ & $\$ 0$ & $\$ 637$ & $\$ 175$ & $\$ 0$ & $\$ 0$ & $\$ 987$ & $\$ 496$ & $\$ 2,295$ \\
\hline 2007 & $\$ 0$ & $\$ 343$ & $\$ 15,628$ & $\$ 38$ & $\$ 5,250$ & $\$ 0$ & $\$ 178$ & $\$ 15,998$ & $\$ 37,435$ \\
\hline 2006 & $\$ 0$ & $\$ 0$ & $\$ 34,876$ & $\$ 1,504$ & $\$ 10,443$ & $\$ 0$ & $\$ 1,274$ & $\$ 9,690$ & $\$ 57,787$ \\
\hline 2005 & $\$ 0$ & $\$ 0$ & $\$ 16,344$ & $\$ 3,091$ & $\$ 12,535$ & $\$ 483$ & $\$ 8,814$ & $\$ 102$ & $\$ 41,369$ \\
\hline 2004 & $\$ 0$ & $\$ 176$ & $\$ 34,321$ & $\$ 6,978$ & $\$ 14,826$ & $\$ 221$ & $\$ 34,124$ & $\$ 101$ & $\$ 90,747$ \\
\hline 2003 & $\$ 0$ & $\$ 0$ & $\$ 15,881$ & $\$ 7,734$ & $\$ 370$ & $\$ 98$ & $\$ 9,888$ & $\$ 61$ & $\$ 34,032$ \\
\hline 2002 & $\$ 56$ & $\$ 0$ & $\$ 2,680$ & $\$ 1,165$ & $\$ 0$ & $\$ 815$ & $\$ 2,664$ & $\$ 36$ & $\$ 7,416$ \\
\hline
\end{tabular}

Source: 2008 FHFA Annual Report to Congress, pp. 108 and 125. 


\section{Exhibit 10}

\section{Monthly Failures of Subprime Mortgage Originators}

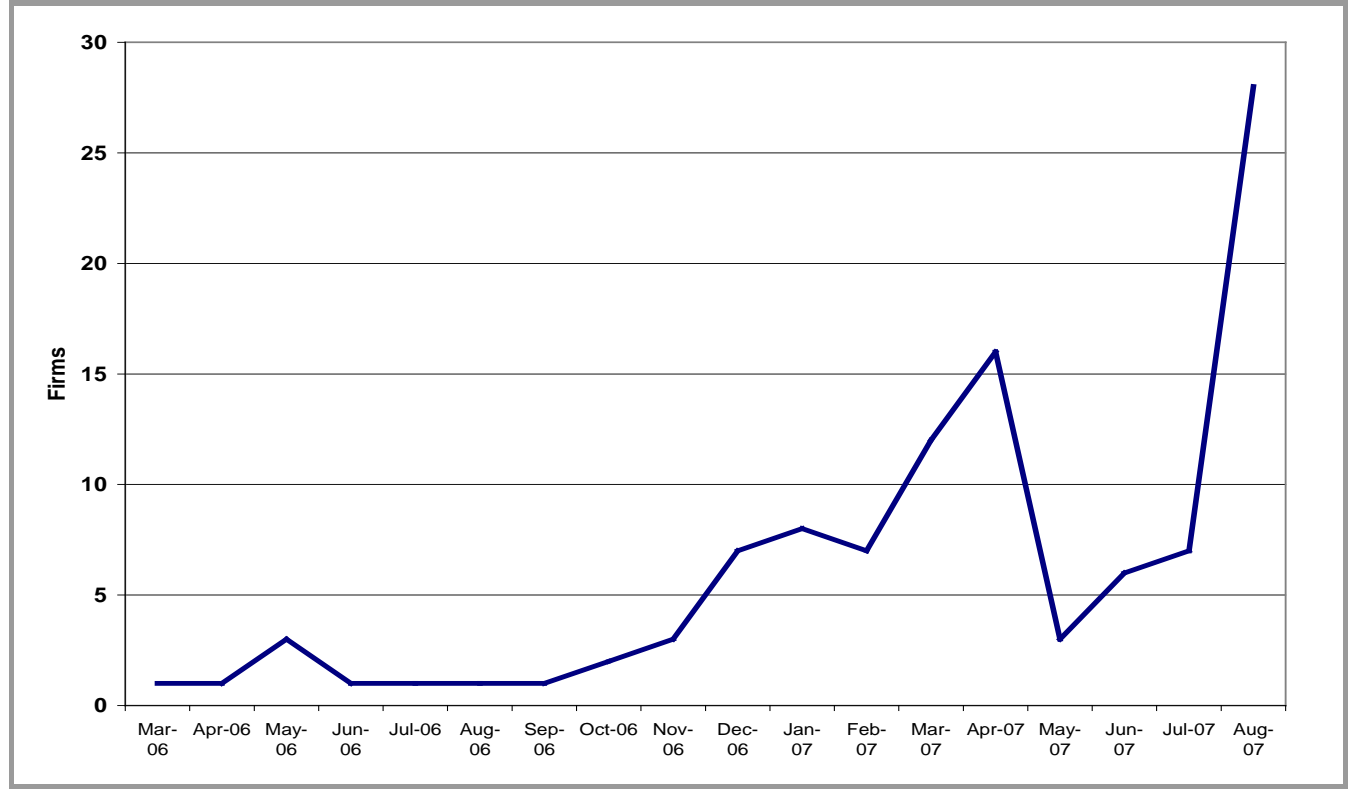

Source: Rick Green, Lehman Shuts Unit; Toll of Lenders Tops 100: Subprime Scorecard, BLOOMBERG, August 23, 2007 


\section{Exhibit 11}

Net Income Loss of Fannie Mae and Freddie Mac: 1992-2008 (\$ millions)

\begin{tabular}{|c|c|c|c|}
\hline Year & $\begin{array}{c}\text { Freddie } \\
\text { Mac }\end{array}$ & $\begin{array}{c}\text { Fannie } \\
\text { Mae }\end{array}$ & Total \\
\hline 1990 & $\$ 414$ & $\$ 1,173$ & $\$ 1,587$ \\
\hline 1991 & $\$ 555$ & $\$ 1,363$ & $\$ 1,918$ \\
\hline 1992 & $\$ 622$ & $\$ 1,623$ & $\$ 2,245$ \\
\hline 1993 & $\$ 786$ & $\$ 1,873$ & $\$ 2,659$ \\
\hline 1994 & $\$ 983$ & $\$ 2,132$ & $\$ 3,115$ \\
\hline 1995 & $\$ 1,091$ & $\$ 2,144$ & $\$ 3,235$ \\
\hline 1996 & $\$ 1,243$ & $\$ 2,725$ & $\$ 3,968$ \\
\hline 1997 & $\$ 1,395$ & $\$ 3,056$ & $\$ 4,451$ \\
\hline 1998 & $\$ 1,700$ & $\$ 3,418$ & $\$ 5,118$ \\
\hline 1999 & $\$ 2,223$ & $\$ 3,912$ & $\$ 6,135$ \\
\hline 2000 & $\$ 3,666$ & $\$ 4,448$ & $\$ 8,114$ \\
\hline 2001 & $\$ 3,158$ & $\$ 5,894$ & $\$ 9,052$ \\
\hline 2002 & $\$ 10,090$ & $\$ 3,914$ & $\$ 14,004$ \\
\hline 2003 & $\$ 4,816$ & $\$ 8,081$ & $\$ 12,897$ \\
\hline 2004 & $\$ 2,937$ & $\$ 4,967$ & $\$ 7,904$ \\
\hline 2005 & $\$ 2,113$ & $\$ 6,347$ & $\$ 8,460$ \\
\hline 2006 & $\$ 2,327$ & $\$ 4,059$ & $\$ 6,386$ \\
\hline 2007 & $-\$ 3,094$ & $-\$ 2,050$ & $-\$ 5,144$ \\
\hline 2008 & $-\$ 50,119$ & $-\$ 58,707$ & $-\$ 108,826$ \\
\hline
\end{tabular}

Source: 2008 FHFA Annual Report to Congress, pp. 110 and 127 